\title{
EFFECT OF FOLIAR SPRAYING OF SOME CHELATED MICROELEMENTS ON GROWTH, YIELD AND CHOCOLATE SPOT DISEASE SEVERITY OF FABA BEAN
}

\author{
Amina I. El-Shafey ${ }^{(1)}$, F. E. Waly ${ }^{(2)}$, A. M. El-Garhy ${ }^{(2)}$ and M. M. H. Rahhal ${ }^{(3)}$ \\ (1) Crop Physiol. Res. Dep., Filed Crops Res. Inst., Agric. Res. Cent., Giza, Egypt. \\ (2) Food Legume Res. Dep., Filed Crops Res. Inst., Agric. Res. Cent., Giza, Egypt. \\ (3) Plant Pathol. Res. Inst., Agric. Res. Cent., Giza, Egypt.
}

Received: Sep. 18, 2019

Accepted: Oct. 28,2019

ABSTERACT: Field experiment using three faba bean cultivars namely Sakha 1, Sakha 4 and Giza 716 was carried out to study the efficacy of foliar spraying chelated Fe, Mn and $\mathrm{Zn}$ individually on vegetative growth, yield and its components, some biochemical constituents and its relation to chocolate spot disease severity caused by Botrytis fabae Sard. during two successive seasons 2017/2018 and 2018/2019 at Etay El-Baroud Agricultural Research Station Farm, El-Beheira Governorate. Sakha $1 \mathrm{cv}$. had the highest shoot dry weight and leaf area/plant in both seasons. Sakha $4 \mathrm{cv}$. was the earliest flowering and maturity in the first and second seasons, respectively. Sakha 4 cultivar had the tallest plant and the heaviest 100-seed weight in both seasons, but Giza 716 had the highest number of pods/plant, seed yield/plant and seed yield/fed. in the first season, however Sakha $4 \mathrm{cv}$. was surpassed the other cultivars in the second season. Chelated $\mathrm{Fe}, \mathrm{Mn}$ and $\mathrm{Zn}$ foliar spray had excellent effects in increasing faba bean growth and yield compared to the fungicide Mancozeb and control treatments. Zn treatment significant increased mean values of shoot dry weight, leaf area/plant, number of branches/plant and seed yield/plant in both seasons. Also, it had the first grade in case of the plant height and seed yield/fed. in the first season, only. Fe treatment significantly increased number of pods/plant and 100-seed weight in the first season, and seed yield/fed. in the second season. Giza $716 \mathrm{cv}$. had the highest content of chlorophyll a, chlorophyll b and chlorophyll $a+b$ in both seasons. Sakha $4 \mathrm{cv}$. had the highest percentage of the seed carbohydrates and protein contents. In case of peroxidase and polyphenol oxidase activities, Giza $716 \mathrm{cv}$. had the first grade. Fe significantly increased chlorophyll a in the first season and chlorophyll $b$ and chlorophyll $a+b$ in both seasons. $Z n$ treatment significantly increased seeds total carbohydrates\%, total protein \%, leaves peroxidase and polyphenol oxidase activities. Sakha $1 \mathrm{cv}$. had the least chocolate spot disease severity in the first season and Giza 716 in the second season. The three tested faba bean cultivars sprayed with Mancozeb reduced disease severity in both seasons followed by Fe in the first season and $\mathrm{Zn}$ in the second one. Data clear that there were negative association between disease severity and peroxidase and polyphenol oxidase activities in all cases. So it could be concluded that the used micronutrients could resist the detrimental effects of Botrytis fabae on the plant growth and improve yield production.

Key words: Chelated microelements, Faba bean, Vegetative growth, Yield and its components, Chlorophyll $a$ and $b$, Peroxidase, Polyphenol oxidase, Chocolate spot disease.

\section{INTRODUCTION}

Faba bean (Vicia faba L.) is belonging to family Fabaceae. It is a multi-purpose crop that plays an important role in the socio-economic life of farming communities (Agegnehu and Fessehaie, 
2006) where it serves as a source of food, feed and is a valuable cheap source of protein (Noorka et al., 2009). In addition, it is an excellent candidate crop to provide nitrogen input into temperate agricultural systems, moreover, it makes a significant contribution to soil fertility restoration as a suitable rotation crop that fixes atmospheric nitrogen (Samuel et al., 2008 and Boubekeur et al., 2012).

Some biotic and abiotic factors are the main reason of the low productivity of faba bean (Agegnehu et al., 2006). Diseases are among the important biotic constrains that limit the production of faba bean crop. Chocolate spot (Botrytis fabae Sard.) and rust (Uromyces fabae (Pers.) Schart) are the economically important diseases that damage the foliage, limiting photosynthetic activity and reduce faba bean production (EIBramawy and Abdul Wahid, 2005 and Torres et al., 2006). In this connection, Omar et al., (1992) who reported that foliar spraying faba bean with Fumazin, $\mathrm{Fe}, \mathrm{Zn}$ and $\mathrm{Mn}$ reduced chocolate spot disease severity. Also, the same trend stated by Rahhal (1993) using the same above micronutrients as faba bean dressing.

Application of green chemistry in agriculture is considered safe methods to control the diseases and produce high quality seeds with lower economic costs (Elwakil et al., 2016). Micronutrients can able to control pathogen damage in plants either directly by antagonizing the pathogen or indirectly through enhancing plant defense mechanism by systemic acquired resistance and or stimulating antagonist population in rhizosphere. Balanced plant nutrients availability can affect the growth rate of the host which can enable host to escape or avoid infection when they are in most susceptible stage, while sufficiency and/or deficiency of plant nutrients may pre-disposed the normal plants to certain diseases (Dutta et al., 2017).

Foliar application of micronutrients generally is more effective, less costly and accepted practice for many crops. In this respect, spraying of micronutrients to plants grown on some soil of Egypt, gave better growth and more yield (AbdEl Hamid and Sarhan, 2008, El-Desuki et al., 2010). Micronutrients have diverse but essential role in plant functioning especially in photosynthesis, respiration, photolysis, protein, carbohydrate metabolism, phenyl-propanoid pathway and also in plant metabolism by affecting the phenolics and lignin content and membrane stability (Dutta et al., 2017). Zinc exerts a great influence on basic plant life processes, such as (i) nitrogen metabolism, uptake of nitrogen and protein quality; (ii) photosynthesischlorophyll synthesis, carbon anhydrase activity; (iii) resistance to abiotic and biotic stresses protection against oxidative damage (Alloway, 2004, Potarzychi and Grzebisz, 2009 and Tekale et al., 2009). Iron has a valuable role in the synthesis of chloroplastic mRNA and rRNA, which control chlorophyll synthesis (Kumawat et al., 2006). Manganese is an essential element of photosystem II where it participates in photolysis (Dutta et al., 2017). Mn is required for biological redo system, enzyme activation, oxygen carrier in nitrogen fixation (Romheld and Marschner, 1995). Recent studies research appeared that a small amount of nutrients, particularly $\mathrm{Zn}, \mathrm{Fe}$ and $\mathrm{Mn}$ applied by foliar spraying increases significantly the yield of crops (Sarkar et al., 2007, Wissuwa et al., 2008, and Sajedi, 2010).

The aim of this study was planned to evaluate the effect of some chelated Fe, $\mathrm{Mn}$ and $\mathrm{Zn}$ micronutrients as safe 
chemicals on faba bean growth, yield, some chemical components and its effect on chocolate spot disease severity caused by Botrytis fabae under field conditions.

\section{MATERIALS AND METHODS}

The present study was carried out at the experimental farm of Itay El-Baroud Agricultural Research Station during the two successive seasons of $2017 / 2018$ and 2018/2019.

\section{Field Experiment:}

The experiment was conducted in split-plot design with three replicates where the three faba bean cultivars Sakha 1, Sakha 4 and Giza 716 cultivars were randomly distributed in the main plots and the five treatments; chelated $\mathrm{Fe}, \mathrm{Zn}, \mathrm{Mn}$, the fungicide Mancozeb ${ }^{\circledR}$ and control allocated in the sub-plots. Seeds of faba bean cultivars used in this investigation were obtained from Legumes Dept., Field Crops Res. Institute, Agric. Res. Center, Giza, Egypt. The plot size was 5 ridges each ridge was three meters long and $70 \mathrm{~cm}$ apart. Seeds were planted on two sides of the ridge at $15 \mathrm{~cm}$ hill spacing with one seed per hill. Faba bean seeds were sown in $5^{\text {th }}$ and $3^{\text {th }}$ of November 2017 and 2018, respectively and all the other cultural practices were carried out according to the recommendations of Ministry of Agriculture and Land Reclamation, Egypt.

\section{Foliar Spraying of the Treatments:}

Faba bean plants were sprayed with the chelated microelements (Fe-EDTA, Mn-EDTA and Zn-EDTA separately) three times at 30, 45 and 60 days after sowing during the two seasons at the rate of $4 \mathrm{~g} / \mathrm{L}$ and at the same time the fungicide (Mancozeb) at the rate of $250 \mathrm{~g} / 100 \mathrm{~L}$ which served as positive control while a treatment sprayed with tap water as negative control.

\section{Character Measurements:}

1 - Growth characters:

Shoot dry weight / plant (g) and leaf area / plant $\left(\mathrm{cm}^{2}\right)$ were estimated as the average of ten plants chosen randomly from the center of the three rows of each plot at 90 days after sowing. The number of days to $50 \%$ flowering and $90 \%$ maturity were recorded. Plant height $(\mathrm{cm})$ and number of branches / plant were estimated as the average of ten plants chosen randomly as mentioned at harvest.

\section{2 - Yield and its components:}

Number of pods / plant, 100-seed weight (g), seed yield / plant (g) and seed yield / feddan $(\mathrm{kg})$ were estimated at harvest time.

\section{3 - Physiological traits:}

3-1-determination of leaf chlorophyll:

Leaves were selected from different positions on the faba bean stem after 90 days from sowing date and homogenized in $5 \mathrm{ml}$ of $85 \%$ cold acetone and centrifuged. The extract was diluted to the appropriate volume. The extract was measured spectrophotometrically at $\mathbf{6 6 3}$ and $647 \mathrm{~nm}$ (Metzner et al., 1965). The chlorophyll content was then expressed as $\mathrm{mg} / \mathrm{g}$ fresh weight.

\section{3-2-determination of total carbohydrate and protein in dried seeds:}

Total carbohydrate was determined using phenol sulphuric method (Dubois et al., 1956). Total nitrogen percentage was determined by Modified MicroKjeldahl method as described by AOAC (1988) and the percentage of protein was calculated by multiplying total $\mathrm{N}$ values by 6.25 . 
Amina I. El-Shafey, et al.,

\section{3-3-determination of Enzyme Activities:}

\section{3-3-a- crude enzyme extract.}

The sample of one $\mathrm{g}$ of leaves (after 90 days from sowing) was homogenized in 2 $\mathrm{ml}$ of $0.1 \mathrm{M}$ sodium phosphate buffer (SPB) $\mathrm{pH} 6.5$ at $4^{\circ} \mathrm{C}$. The filtrate was centrifuged at $20,000 \mathrm{rpm}$ at $4^{\circ} \mathrm{C}$ for 15 min. The supernatant served as an enzyme extract for enzyme assay of polyphenol oxidase and peroxidase.

\section{3-3-b-peroxidase activity:}

Peroxidase activity was assayed colorimetrically according to the method described by (Amako et al., 1994). Peroxidase enzyme activity was expressed as change in absorbance at $430 \mathrm{~nm}$ per $\mathrm{min} / \mathrm{g}$ fresh leaves.

\section{3-3-c-polyphenol oxidase (PPO) activity:}

Polyphenol oxidase activity was estimated as described by Mayer and Harel (1979) with some modifications. The polyphenol oxidase activity was expressed as change in absorbance at $495 \mathrm{~nm}$ per $\mathrm{min} / \mathrm{g}$ fresh leaves.

\section{4-Determination of chocolate spot disease severity:}

Severity due to natural infection was determined after 75, 90 and 105 days from sowing. Ten randomly pre-tagged faba bean plants in the three central rows, visual disease severity score on leaves was rated using 1-9 rating scale (Bernier et al., 1993), where 1= no disease symptoms or very small specks; $3=$ few small discrete lesions; $5=$ some coalesced lesions with some defoliation; $7=$ large coalesced sporulating lesions, $50 \%$ defoliation and some dead plant; and $9=$ extensive lesions on leaves, stems and pods, severe defoliation, heavy sporulation, stem girdling, blackening and death of more than $80 \%$ of plants (Bernier et al., 1984). Chocolate spot disease severity \% was assessed according to the following formula:
Disease severity $\%=\Sigma(n X$ v)/9N) $X 100$, Where: $(n)=$ Number of plants in each category; $(v)=$ Numerical values of symptoms category; $(\mathrm{N})=$ Total number of plants; $(9)=$ Maximum numerical value of symptom category.

Then efficacy percentage ( $E \%$ ) of each compound in reducing disease, severity percentage of faba bean was assessed according to the equation adapted by Rewal and Jhooty (1985) as follow:-

$$
E \%=(C-T / C) X 100
$$

Where: $\mathbf{C}=$ Disease severity $\%$ in control treatment; $\mathbf{T}=$ Disease severity $\%$ in the treatment

\section{Statistical analysis:}

All data were subjected to the analyses of variance (ANOVA) for splitplot design followed by compared means with LSD at level probability 5\% according to (Gomez and Gomez, 1984).

\section{RESULTS AND DISCUSSION}

1- Effect of cultivars, foliar application treatments and their interaction on shoot dry weight/plant and leaf area / plant after 90 days from sowing in 2017/2018 and 2018/2019 growing seasons:

The data presented in Table (1) show that Sakha $1 \mathrm{cv}$. had the highest shoot dry weight (14.54 and $19.32 \mathrm{~g}$ ) and leaf area/plant (1203.43 and $1754.26 \mathrm{~cm}^{2}$ ) in the first and second seasons, respectively. Also results indicate that chelated $\mathrm{Fe}, \mathrm{Mn}$ and $\mathrm{Zn}$ foliar spray had excellent effects in increasing faba bean parameters mentioned above compared to Mancozeb and control treatments. Foliar application of $\mathrm{Zn}$ had the highest mean values with averages of 17.60 and $23.53(\mathrm{~g})$ and 1577.97 and $2082.80\left(\mathrm{~cm}^{2}\right)$ for shoot dry weight and leaf area / plant for the two seasons, respectively followed by Mn and Fe treatments. 
Table (1): Effect of cultivars, foliar application treatments and their interaction on shoot dry weight/plant $(\mathrm{g})$ and leaf area/plant $\left(\mathrm{cm}^{2}\right)$ during two successive seasons after 90 days under field conditions.

\begin{tabular}{|c|c|c|c|c|c|}
\hline \multicolumn{2}{|c|}{ Parameter } & \multicolumn{2}{|c|}{ Shoot dry weight/plant (g) } & \multicolumn{2}{|c|}{ Leaf area/plant $\left(\mathrm{cm}^{2}\right)$} \\
\hline \multicolumn{2}{|c|}{ Factor Season } & $2017 / 2018$ & $2018 / 2019$ & 2017/2018 & 2018/2019 \\
\hline \multicolumn{6}{|c|}{ Cultivar ( C ) } \\
\hline \multicolumn{2}{|l|}{ Sakha 1} & 14.54 & $19.32^{\mathrm{a}}$ & 1203.43 & $1754.26^{a}$ \\
\hline \multicolumn{2}{|l|}{ Sakha 4} & 13.23 & $18.74^{\mathrm{a}}$ & 1114.17 & $1251.95^{b}$ \\
\hline \multicolumn{2}{|l|}{ Giza 716} & 12.49 & $14.88^{b}$ & 1041.84 & $1268.06^{b}$ \\
\hline \multicolumn{6}{|c|}{ Treatment ( $\mathrm{T}$ ) } \\
\hline \multicolumn{2}{|l|}{$\mathrm{Fe}$} & $14.30^{b}$ & $17.08^{b}$ & $1027.73^{b}$ & $1357.47^{c}$ \\
\hline \multicolumn{2}{|l|}{ Mn } & $15.12^{a b}$ & $21.44^{\mathrm{a}}$ & $1409.90^{a}$ & $1769.83^{b}$ \\
\hline \multicolumn{2}{|l|}{ Zn } & $17.60^{\mathrm{a}}$ & $23.53^{a}$ & $1577.97^{\mathrm{a}}$ & $2082.80^{a}$ \\
\hline \multicolumn{2}{|l|}{ Mancozeb } & $10.66^{c}$ & $14.46^{b c}$ & $842.89^{b c}$ & $1035.63^{d}$ \\
\hline \multicolumn{2}{|l|}{ Control } & $9.75^{c}$ & $11.73^{c}$ & $740.57^{c}$ & $878.07^{d}$ \\
\hline \multicolumn{6}{|c|}{ Interaction (CXT) } \\
\hline \multirow{5}{*}{ Sakha 1} & $\mathrm{Fe}$ & 18.55 & 20.99 & 1117.38 & 1666.43 \\
\hline & Mn & 16.31 & 22.97 & 1333.87 & 2332.06 \\
\hline & $\mathrm{Zn}$ & 15.76 & 23.69 & 1731.88 & 2473.48 \\
\hline & Mancozeb & 11.13 & 15.78 & 952.36 & 1162.80 \\
\hline & Control & 10.96 & 13.17 & 881.64 & 1136.56 \\
\hline \multirow{5}{*}{ Sakha 4} & $\mathrm{Fe}$ & 11.45 & 16.33 & 1050.77 & 1235.97 \\
\hline & Mn & 14.63 & 24.63 & 1447.42 & 1441.36 \\
\hline & $\mathrm{Zn}$ & 17.76 & 24.04 & 1431.62 & 1636.15 \\
\hline & Mancozeb & 11.47 & 15.99 & 900.38 & 1049.76 \\
\hline & Control & 10.85 & 12.70 & 740.52 & 896.51 \\
\hline \multirow{5}{*}{ Giza 716} & $\mathrm{Fe}$ & 12.89 & 13.91 & 1415.05 & 1170.02 \\
\hline & Mn & 14.42 & 16.72 & 1448.40 & 1536.06 \\
\hline & $\mathrm{Zn}$ & 19.29 & 22.85 & 1570.26 & 2138.78 \\
\hline & Mancozeb & 8.39 & 11.60 & 675.93 & 894.33 \\
\hline & Control & 7.45 & 9.33 & 599.56 & 601.13 \\
\hline \multicolumn{2}{|c|}{ LSD 5\% Cultivar ( C ) } & NS & 2.60 & NS & 231.69 \\
\hline \multicolumn{2}{|c|}{ LSD 5\% Treatment (T) } & 2.69 & 3.35 & 211.47 & 299.11 \\
\hline \multicolumn{2}{|c|}{ LSD $5 \% \mathrm{C} \times \mathrm{T}$} & 4.65 & 5.80 & 366.27 & 557.90 \\
\hline
\end{tabular}

Means in the same column followed by the same letter (s) are not significant according to L.S.D 0.05 values. 
Also, the statistical analysis showed that the differences between spraying treatments were significant, especially between the microelements from one side and Mancozeb and control treatments from another side in the two seasons. The control treatment (untreated) had lower values of shoot dry weight $(\mathrm{g})$ and leaf area/plant $\left(\mathrm{cm}^{2}\right)$ in the two seasons.

From data presented in the same Table, it is clear that there are significant differences between the interaction of faba bean cultivars and the spraying chelated micronutrients in both seasons. As for the interactions between faba bean cv. and treatments the obtained data in Table 1 indicated that, Giza $716 \mathrm{cv}$. under spraying $\mathrm{Zn}$ had the highest shoot dry weight $(19.29 \mathrm{~g})$ and leaf area (1570.26 $\mathrm{cm}^{2}$ in the first season. While, Sakha 4 cv. $\mathrm{X} M \mathrm{n}$ had the highest shoot dry weight in the second season with average of $24.63 \mathrm{~g}$. finally, Sakha $1 \mathrm{cv}$. $x$ $\mathrm{Zn}$ had the highest leaf area in the second season with an average of $2473.48 \mathrm{~cm}^{2}$.

Tharanathan and Mahadevamma (2003) stated that foliar application of $\mathrm{Zn}$ at different growth stages increased the leaf area index of bean. Also, El-Sallami and Gad (2005) reported that $\mathrm{Zn}$ increased the vegetative growth measurements plant height, number of leaves as well as the fresh and dry weights of aster plants. Ghasemian et al. (2010) revealed a significant positive effect of $\mathrm{Zn}$ treatment on the dry matter of soybean. In this respect, $\mathrm{Zn}$ has a significant role in cell elongation and synthesis of tryptophan (precursor of indole-3-acetic acid). Increased elongation of cells in the early stages of plant growth can lead to greater plant height and dry weight of maize (Memari Tabrizi et al., 2011).

Application of $\mathrm{Zn}$ or $\mathrm{Fe}$ has been reported significant positive effects, in most cases, on growth measurements of common bean (Fernandes et al., 2007). Statistically, data were significant between the three cultivars tested in case of shoot dry weight and leaf area / plant in the second season, only.

Abd El-azeem et al., (2014) exhibited the positive effect of foliar application with $\mathrm{Fe}, \mathrm{Zn}$ or $\mathrm{B}$ on the performance of faba bean genotypes (local cultivar Hassawi 2 and new developed Population 4). Similar results were obtained by ElFiki et al., (2008) and Knany et al. (2009) who stated that growth and yield parameters were positively affected by the application of $\mathrm{Zn}, \mathrm{Mn}$ and Fe either individually or in mixtures.

\section{2- Effect of cultivar, foliar application treatments and their interaction on days to flowering and maturity dates in 2017/2018 and 2018/2019 growing seasons:}

Data in Table (2) appear that Sakha 4 and Sakha $1 \mathrm{cv}$. are earliest in flowering date than Giza $716 \mathrm{cv}$. in the first season with averages of $48.33,48.47$ and 49.73 days, respectively, but in the second season this parameter differed where cultivar Giza 716 was the earliest followed by Sakha 1 and Sakha 4 cv. with averages of $47.60,50.33$ and 52.13 days, respectively. In case of maturity date, Sakha 1 and Sakha 4 cultivars had the earliest mature in the first and second seasons with averages of 145.26 and 140.43 days, respectively. The statistical analysis showed that the differences between foliar spraying were not significant for flowering date and significant for maturity date in both seasons. In the same Table the control treatment showed the earliest mature plants in both seasons with averages of 145.89 and 138.78 days, respectively. 
Table (2): Effect of cultivars, foliar application treatments and their interaction on days to flowering and maturity dates during two successive seasons under field condition.

\begin{tabular}{|c|c|c|c|c|c|}
\hline \multicolumn{2}{|c|}{ Parameter } & \multicolumn{2}{|c|}{ Days to flowering } & \multicolumn{2}{|c|}{ Days to maturity } \\
\hline \multicolumn{2}{|c|}{ Factor Season } & $2016 / 2017$ & $2017 / 2018$ & $2016 / 2017$ & $2017 / 2018$ \\
\hline \multicolumn{6}{|c|}{ Cultivar ( C ) } \\
\hline \multicolumn{2}{|c|}{ Sakha 1} & $48.47^{b}$ & $50.33^{\mathrm{ab}}$ & $145.26^{c}$ & $143.54^{a}$ \\
\hline \multicolumn{2}{|l|}{ Sakha 4} & $48.33^{b}$ & $52.13^{\mathrm{a}}$ & $148.67^{b}$ & $140.43^{b}$ \\
\hline \multicolumn{2}{|l|}{ Giza 716} & $49.73^{a}$ & $47.60^{b}$ & $149.93^{a}$ & $141.40^{a b}$ \\
\hline \multicolumn{6}{|c|}{ Treatment ( $\mathrm{T}$ ) } \\
\hline \multicolumn{2}{|l|}{$\mathrm{Fe}$} & 49.00 & 50.33 & $149.78^{a}$ & $141.00^{b}$ \\
\hline \multicolumn{2}{|l|}{ Mn } & 49.22 & 49.78 & $147.45^{b}$ & $139.45^{b}$ \\
\hline \multicolumn{2}{|l|}{ Zn } & 48.11 & 50.67 & $149.11^{a}$ & $145.00^{a}$ \\
\hline \multicolumn{2}{|l|}{ Mancozeb } & 48.89 & 49.56 & $147.56^{b}$ & $145.56^{a}$ \\
\hline \multicolumn{2}{|l|}{ Control } & 49.00 & 49.89 & $145.89^{c}$ & $138.78^{b}$ \\
\hline \multicolumn{6}{|c|}{ Interaction (CxT) } \\
\hline \multirow{5}{*}{ Sakha 1} & $\mathrm{Fe}$ & 49.33 & 53.33 & 146.33 & 145.67 \\
\hline & Mn & 48.33 & 48.00 & 144.67 & 140.67 \\
\hline & $\mathrm{Zn}$ & 47.33 & 52.00 & 147.33 & 145.67 \\
\hline & Mancozeb & 48.00 & 47.67 & 143.33 & 145.67 \\
\hline & Control & 49.33 & 50.67 & 144.33 & 140.00 \\
\hline \multirow{5}{*}{ Sakha 4} & $\mathrm{Fe}$ & 47.67 & 49.33 & 150.67 & 138.33 \\
\hline & Mn & 50.00 & 53.33 & 147.67 & 139.00 \\
\hline & $\mathrm{Zn}$ & 48.00 & 54.69 & 148.67 & 142.00 \\
\hline & Mancozeb & 48.33 & 53.67 & 149.00 & 145.33 \\
\hline & Control & 47.67 & 51.00 & 147.33 & 140.00 \\
\hline \multirow{5}{*}{ Giza 716} & $\mathrm{Fe}$ & 50.00 & 49.33 & 152.33 & 139.00 \\
\hline & Mn & 49.33 & 48.00 & 150.00 & 138.67 \\
\hline & Zn & 49.00 & 45.33 & 151.33 & 147.33 \\
\hline & Mancozeb & 50.33 & 47.33 & 150.00 & 145.67 \\
\hline & Control & 50.00 & 48.00 & 146.00 & 136.33 \\
\hline \multicolumn{2}{|c|}{ LSD 5\% Cultivar (C) } & 0.87 & 3.99 & 1.20 & 2.23 \\
\hline \multicolumn{2}{|c|}{ LSD 5\% Treatment (T) } & NS & NS & 1.55 & 2.88 \\
\hline \multicolumn{2}{|c|}{ LSD 5\% C x T } & 1.95 & 2.84 & 2.23 & 4.14 \\
\hline
\end{tabular}

Means in the same column followed by the same letter (s) are not significant according to L.S.D 0.05 values. 
As for the interaction effect, Sakha 1 cv. $x \mathrm{Zn}$ in the first season and Giza 716 cv. $x \mathrm{Zn}$ in the second season showed the lowest flowering dates with averages of 47.33 and 45.33 days, respectively. While, the interactions of Sakha $1 \mathrm{cv} . x$ Mancozeb in the first season and Giza $716 \mathrm{cv}$. $x$ control in the second season had the earliest mature plants with averages of 143.33 and 136.33 days, respectively.

$\mathrm{Zn}$ is a component of important enzymes such as proteinase, peptidase and dehydrogenase, which promotes starch formation, seed maturation and production (Laware and Raskar, 2014). Also, $\mathrm{Zn}$ may be required for pollen function and fertilization (Pandey et al., 2006).

\section{3- Effect of cultivars, foliar} application treatments and their interaction on yield and yield components in 2017/2018 and 2018/2019 growing seasons:

Data presented in Tables (3- $a$ and b) showed that Sakha $4 \mathrm{cv}$. had the tallest plants with mean values in both seasons of $(106.20$ and $111.40 \mathrm{~cm})$. Giza $716 \mathrm{cv}$. exceeded the three cultivars in the number of branches / plant in both seasons with averages of 1.80 and 1.76 , respectively. In case of 100-seed weight Sakha $4 \mathrm{cv}$. had the first grade with averages of (80.50 and $91.11 \mathrm{~g}$ ) and the second grade with the number of pods / plant, seed yield / plant (g) and seed yield/fed. (kg) with averages of 8.95 , $16.19(\mathrm{~g})$ and $1353.33(\mathrm{~kg})$, respectively in the first season. The differences between the foliar spraying treatments were significant in both seasons. Zn had the highest significant mean values for plant height $(110.00 \mathrm{~cm})$, number of branches/plant (1.91), seed yield/plant $(17.75 \mathrm{~g})$ and seed yield/fed. $(1435.00 \mathrm{~kg})$ in the first season. In the same season Fe had the highest number of pods/plant
(10.09) and 100-seed weight (79.63). In the second season, $\mathrm{Zn}$ showed the highest number of branches/plant (1.87), number of pods/plant (10.96) and seed yield/plant $(21.77 \mathrm{~g})$ while $\mathrm{Fe}$ had the highest 100 -seed weight $(89.81 \mathrm{~g})$ and seed yield/fed. $(1815.33 \mathrm{~kg})$. Finally, the tallest plants were obtained under $\mathrm{Mn}$ treatment with average of $112.56 \mathrm{~cm}$.

As for the interaction effect, data in Table 3-a indicated that in the first season the interaction of Giza $716 \mathrm{cv}$. x Fe gave the highest number of pods/plant (11.08) and seed yield/plant (18.73 g), while Giza $716 \mathrm{cv}$. $x$ Zn showed the highest number of branches/plant (3.07) and 100-seed weight $(86.66 \mathrm{~g})$. In the same season sprayed Sakha $4 \mathrm{cv}$. with Fe gave the highest seed yield/fed $(1596.93 \mathrm{~kg})$. In the second season, the obtained date in Table 3-b showed that spraying Sakha $4 \mathrm{cv}$. with Fe gave the highest 100-ssed weight $(96.62 \mathrm{~g})$ and seed yield/fed $(1997.80 \mathrm{~kg}) \quad$ while, spraying Sakha $4 \mathrm{cv}$. with $\mathrm{Zn}$ gave the highest number of pods/plant (11.80) and seed yield/plant (22.62). On the other side, Giza $716 \mathrm{cv}$. under Zn treatment showed the highest number of branches/plant (2.07). Also, sprayed Giza $716 \mathrm{cv}$. with Mn gave the tallest plant in both seasons with averages of 114.67 and $118.67 \mathrm{~cm}$ respectively.

These results are in agreement with the findings mentioned by Ibrahim et al., (2007) who, reported that foliar application of micronutrients significantly increased faba bean plant height, number of branches, leaf area as well as number of pods / plant and consequently the seed yield. Chelated $\mathrm{Fe}, \mathrm{Mn}$ and $\mathrm{Zn}$ foliar spray had excellent effects in increasing faba bean seed yield and yield components significantly more than Mancozeb and control treatments (positive and negative check treatments). In this respect, Bameri, et al., (2012) showed that $\mathrm{Fe}, \mathrm{Mn}$ and $\mathrm{Zn}$ individually 
and combined can be easily sprayed on leaf, thus leaves chlorophyll concentration increased, which in turn, lead to increase in plant height and yield of wheat.

Also, Bozorgi et al., (2011) reported that spraying faba bean plants with $\mathrm{Zn}$ increase number of pods/plant and 100- seed weight. Sharaf et al., (2009) mentioned that foliar treatment of broad bean and lupin with either Boron (75 ppm) or Zinc (100 ppm) showed significant stimulation in most of the growth and yield characteristics for both plants.

Table (3-a): Effect of cultivars, foliar application treatments and their interaction on yield and yield components in the first season 2017/2018.

\begin{tabular}{|c|c|c|c|c|c|c|c|}
\hline \multicolumn{2}{|c|}{\begin{tabular}{ll|} 
Factor & Parameter \\
\end{tabular}} & \multirow{2}{*}{$\begin{array}{c}\text { Plant } \\
\text { height } \\
(\mathrm{cm})\end{array}$} & \multirow{2}{*}{$\begin{array}{l}\text { No. of } \\
\text { branches/ } \\
\text { plant }\end{array}$} & \multirow{2}{*}{$\begin{array}{l}\text { No. of } \\
\text { pods/ } \\
\text { plant }\end{array}$} & \multirow{2}{*}{$\begin{array}{l}\text { 100-seed } \\
\text { weight } \\
\text { (g) }\end{array}$} & \multirow{2}{*}{$\begin{array}{c}\text { Seed } \\
\text { yield/plant } \\
(\mathrm{g})\end{array}$} & \multirow{2}{*}{$\begin{array}{c}\text { Seed } \\
\text { yield/fed. } \\
(\mathbf{k g})\end{array}$} \\
\hline \multicolumn{2}{|c|}{ Cultivar ( C ) } & & & & & & \\
\hline \multicolumn{2}{|c|}{ Sakha 1} & $98.93^{b}$ & $1.56^{b}$ & $7.72^{b}$ & $69.24^{b}$ & 15.42 & $1060.59^{b}$ \\
\hline \multicolumn{2}{|l|}{ Sakha 4} & $106.20^{a}$ & $1.37^{b}$ & $8.95^{a}$ & $80.50^{a}$ & 16.19 & $1353.33^{a}$ \\
\hline \multicolumn{2}{|l|}{ Giza 716} & $105.60^{a}$ & $1.80^{\mathrm{a}}$ & $9.20^{\mathrm{a}}$ & $79.45^{a}$ & 16.71 & $1378.24^{a}$ \\
\hline \multicolumn{8}{|c|}{ Treatment ( $\mathrm{T}$ ) } \\
\hline \multicolumn{2}{|c|}{$\mathrm{Fe}$} & $104.22^{b}$ & $1.78^{a}$ & $10.09^{a}$ & $79.63^{\mathrm{a}}$ & $16.96^{\mathrm{ab}}$ & $1375.27^{b}$ \\
\hline \multicolumn{2}{|l|}{ Mn } & $108.78^{a}$ & $1.67^{\mathrm{a}}$ & $9.10^{b}$ & $78.82^{\mathrm{ab}}$ & $16.81^{a b}$ & $1353.02^{b}$ \\
\hline \multicolumn{2}{|l|}{ Zn } & $110.00^{a}$ & $1.91^{\mathrm{a}}$ & $9.78^{a b}$ & $78.80^{\mathrm{ab}}$ & $17.75^{\mathrm{a}}$ & $1435.00^{a}$ \\
\hline \multicolumn{2}{|c|}{ Mancozeb } & $99.56^{c}$ & $1.36^{b}$ & $7.53^{c}$ & $73.77^{\mathrm{ab}}$ & $15.37^{b c}$ & $1103.07^{c}$ \\
\hline \multicolumn{2}{|c|}{ Control } & $95.34^{d}$ & $1.18^{b}$ & $6.62^{c}$ & $70.97^{b}$ & $13.63^{c}$ & $1053.94^{d}$ \\
\hline \multicolumn{8}{|c|}{ Interaction (CxT) } \\
\hline \multirow{5}{*}{ Sakha 1} & $\mathrm{Fe}$ & 98.33 & 1.67 & 8.67 & 77.87 & 14.45 & 1039.27 \\
\hline & $M n$ & 103.67 & 1.93 & 8.30 & 73.50 & 15.89 & 1049.53 \\
\hline & $Z n$ & 105.33 & 1.87 & 9.21 & 66.75 & 18.64 & 1184.87 \\
\hline & Mancozeb & 94.67 & 1.33 & 7.05 & 64.35 & 14.38 & 1020.47 \\
\hline & Control & 95.67 & 1.00 & 5.36 & 63.73 & 13.71 & 1008.87 \\
\hline \multirow{5}{*}{ Sakha 4} & $\mathrm{Fe}$ & 105.67 & 1.67 & 10.54 & 77.78 & 17.71 & 1596.93 \\
\hline & $M n$ & 108.00 & 1.33 & 9.49 & 83.92 & 17.49 & 1557.27 \\
\hline & $Z n$ & 110.67 & 1.80 & 10.01 & 82.99 & 16.38 & 1583.87 \\
\hline & Mancozeb & 104.00 & 1.07 & 7.06 & 79.35 & 15.76 & 1021.53 \\
\hline & Control & 102.67 & 1.00 & 7.66 & 78.45 & 13.59 & 1007.07 \\
\hline \multirow{5}{*}{ Giza 716} & $\mathrm{Fe}$ & 108.67 & 2.00 & 11.08 & 83.23 & 18.73 & 1489.60 \\
\hline & $M n$ & 114.67 & 1.73 & 9.50 & 79.03 & 17.04 & 1452.27 \\
\hline & $Z n$ & 114.00 & 3.07 & 10.13 & 86.66 & 18.22 & 1536.27 \\
\hline & Mancozeb & 100.00 & 1.67 & 8.46 & 77.60 & 15.96 & 1267.20 \\
\hline & Control & 90.67 & 1.53 & 6.82 & 70.72 & 13.59 & 1145.87 \\
\hline \multicolumn{2}{|c|}{ LSD 5\% Cultivar(C) } & 1.96 & 0.19 & 0.71 & 6.26 & NS & 36.96 \\
\hline \multicolumn{2}{|c|}{ LSD 5\% Treatment(T) } & 2.54 & 0.25 & 0.92 & 0.08 & 2.26 & 47.71 \\
\hline \multicolumn{2}{|c|}{ LSD 5\% C x T } & 4.39 & 0.43 & 1.59 & 13.99 & 3.91 & 88.64 \\
\hline
\end{tabular}

Means in the same column followed by the same letter (s) are not significant according to L.S.D 0.05 values. 
Amina I. El-Shafey, et al.,

Table (3-b): Effect of cultivars, foliar application treatments and their interaction on yield and yield components in the second season 2018/2019.

\begin{tabular}{|c|c|c|c|c|c|c|c|}
\hline \multicolumn{2}{|c|}{ Factor } & \multirow{2}{*}{$\begin{array}{c}\text { Plant } \\
\text { height } \\
(\mathrm{cm})\end{array}$} & \multirow{2}{*}{$\begin{array}{c}\text { No. of } \\
\text { branches/ } \\
\text { plant }\end{array}$} & \multirow{2}{*}{$\begin{array}{l}\text { No. of } \\
\text { pods/ } \\
\text { plant }\end{array}$} & \multirow{2}{*}{$\begin{array}{c}\text { 100-seed } \\
\text { weight } \\
\text { (g) }\end{array}$} & \multirow{2}{*}{$\begin{array}{c}\text { Seed } \\
\text { yield/plant } \\
\text { (g) }\end{array}$} & \multirow{2}{*}{$\begin{array}{c}\text { Seed } \\
\text { yield/fed } \\
(\mathbf{k g})\end{array}$} \\
\hline \multicolumn{2}{|c|}{ Cultivar ( C ) } & & & & & & \\
\hline \multicolumn{2}{|l|}{ Sakha 1} & $102.00^{c}$ & $1.44^{b}$ & $8.64^{b}$ & $84.49^{b}$ & 18.07 & $1324.12^{b}$ \\
\hline \multicolumn{2}{|l|}{ Sakha 4} & $111.40^{\mathrm{a}}$ & $1.59^{b}$ & $9.73^{a}$ & $91.11^{a}$ & 19.33 & $1694.11^{\mathrm{a}}$ \\
\hline \multicolumn{2}{|l|}{ Giza 716} & $107.47^{b}$ & $1.76^{\mathrm{a}}$ & $9.09^{a b}$ & $84.15^{b}$ & 18.09 & $1587.49^{a}$ \\
\hline \multicolumn{8}{|c|}{ Treatment ( $\mathrm{T}$ ) } \\
\hline \multicolumn{2}{|l|}{$\mathbf{F e}$} & $111.56^{\mathrm{a}}$ & $1.71^{a}$ & $10.58^{a}$ & $89.81^{a}$ & $19.34^{b}$ & $1815.33^{a}$ \\
\hline \multicolumn{2}{|l|}{ Mn } & $112.56^{a}$ & $1.71^{a}$ & $9.96^{\mathrm{a}}$ & $87.64^{b}$ & $20.14^{a b}$ & $1496.13^{b}$ \\
\hline \multicolumn{2}{|l|}{$\mathrm{Zn}$} & $111.11^{a}$ & $1.87^{\mathrm{a}}$ & $10.96^{\mathrm{a}}$ & $88.06^{a b}$ & $21.77^{a}$ & $1770.09^{a}$ \\
\hline \multicolumn{2}{|c|}{ Mancozeb } & $102.89^{b}$ & $1.51^{b}$ & $7.87^{b}$ & $84.97^{c}$ & $16.55^{\mathrm{c}}$ & $1404.87^{b}$ \\
\hline \multicolumn{2}{|l|}{ Control } & $96.47^{\mathrm{c}}$ & $1.18^{c}$ & $6.42^{c}$ & $82.44^{d}$ & $14.69^{\mathrm{C}}$ & $1189.78^{c}$ \\
\hline \multicolumn{8}{|c|}{ Interaction (CxT) } \\
\hline \multirow{5}{*}{ Sakha 1} & $\mathrm{Fe}$ & 107.67 & 1.60 & 9.67 & 87.60 & 17.88 & 1548.87 \\
\hline & Mn & 109.33 & 1.40 & 10.07 & 87.87 & 19.41 & 1195.13 \\
\hline & Zn & 103.33 & 1.67 & 10.60 & 86.11 & 21.07 & 1689.33 \\
\hline & Mancozeb & 97.67 & 1.47 & 7.87 & 81.17 & 16.23 & 1135.40 \\
\hline & Control & 92.00 & 1.07 & 5.00 & 79.69 & 15.77 & 1051.87 \\
\hline \multirow{5}{*}{ Sakha 4} & $\mathrm{Fe}$ & 113.33 & 1.73 & 10.80 & 96.62 & 21.84 & 1997.80 \\
\hline & Mn & 109.67 & 1.80 & 10.13 & 90.73 & 20.90 & 1678.60 \\
\hline & Zn & 116.67 & 1.87 & 11.80 & 93.15 & 22.62 & 1996.93 \\
\hline & Mancozeb & 110.67 & 1.33 & 8.07 & 87.81 & 16.63 & 1596.47 \\
\hline & Control & 106.67 & 1.20 & 7.87 & 87.28 & 14.65 & 1200.73 \\
\hline \multirow{5}{*}{ Giza 716} & $\mathrm{Fe}$ & 113.67 & 1.80 & 11.27 & 85.20 & 18.28 & 1899.33 \\
\hline & Mn & 118.67 & 1.93 & 9.67 & 84.31 & 20.10 & 1614.67 \\
\hline & $Z n$ & 113.33 & 2.07 & 10.47 & 84.91 & 21.60 & 1624.00 \\
\hline & Mancozeb & 100.33 & 1.73 & 7.67 & 85.93 & 16.80 & 1482.73 \\
\hline & Control & 91.33 & 1.27 & 6.40 & 80.37 & 13.64 & 1316.73 \\
\hline \multicolumn{2}{|c|}{ LSD 5\% Cultivar (C ) } & 2.81 & 0.15 & 0.91 & 1.57 & NS & 120.95 \\
\hline \multicolumn{2}{|c|}{ LSD 5\%Treatment (T) } & 2.62 & 0.20 & 1.18 & 2.02 & 2.11 & 156.15 \\
\hline \multicolumn{2}{|c|}{ LSD 5\% C x T } & 6.28 & 0.30 & 3.50 & 3.50 & 3.66 & 224.60 \\
\hline
\end{tabular}

Means in the same column followed by the same letter (s) are not significant according to L.S.D 0.05 values. 
4- Effect of cultivars, foliar application treatments and their interaction on chlorophyll. $a, b$ and $a+b$ in 2017/2018 and 2018/2019 growing seasons:

Data presented in Table (4) clear that the significant differences were obtained among all cultivars in the three traits except chlorophyll $a$ and $a+b$ in the first season. Giza $716 \mathrm{cv}$. had the highest contents of chlorophyll a (0.80 and 0.90 $\mathrm{mg} / \mathrm{g} \mathrm{f.w}$ ), chlorophyll b (0.47 and 0.49 $\mathrm{mg} / \mathrm{g} \mathrm{f.w}$ ) and chlorophyll $a+b$ (1.27 and $1.39 \mathrm{mg} / \mathrm{g} \mathrm{f.w})$ in both seasons, respectively. Sakha $4 \mathrm{cv}$. had the second grade. Also, the results indicate that foliar spraying of chelated micronutrients had excellent effects in increasing the leaves chlorophyll content of the tested faba bean cultivars. $\mathrm{Fe}, \mathrm{Mn}$ and $\mathrm{Zn}$ caused significantly increased chlorophyll a, chlorophyll b and chlorophyll $a+b$ compared to Mancozeb and control treatments. These results are in harmony with that reported by Sharaf et al., (2009) who reported that photosynthetic pigments increased in broad bean leaves with foliar application of $B$ and $\mathrm{Zn}$. The same trend mentioned by Elwakil et al., (2016) who reported that $\mathrm{Zn}$ and $\mathrm{Fe}$ in the form of seed soaking or foliar spraying increased faba bean leaves chlorophyll $\mathbf{a}, \mathbf{b}$ and carotenoids. Tobbal (2006) showed that, spraying Celosia plants with $\mathrm{Zn}$ increased contents of chlorophyll $a, b$ and total chlorophyll $(a+b)$, the increase in chlorophyll could be ascribed to the effect of this element on increasing the biosynthesis of photosynthetic pigments and/or retarding their degradation. Also, from the same Table the differences between the values of chlorophyll $a, b$ and $a+b$ obtained from the interaction between the three cultivars and foliar spraying treatments mentioned before are significant in all cases. The data revealed that significantly increased the three cultivars content of chlorophyll a, b and $a+b$ compared to mancozeb and control treatments. $\mathrm{Zn}$ followed by Mn then Fe showed the highest contents of chlorophyll $a, b$ and $a+b$ in the three cultivars in both seasons.

5- Effect of cultivars, foliar application treatments and their interaction on seed content of total carbohydrates and protein (\%), peroxidase and polyphenol oxidase activities ( $\mathrm{mg} / \mathrm{g}$ leaves fresh weight $/ \mathrm{min}$ ) in the second season 2018/2019 :

From data presented in Table (5), it clear that the differences between the three cultivars were significant for peroxidase activity and insignificant for poly phenol oxidase, total carbohydrates and protein. Sakha $4 \mathrm{cv}$. had the highest percentages of the total carbohydrates and total protein of seed contents with averages of 52.40 and $24.08 \%$, respectively. Also, Sakha 4 and Giza 716 cultivars had the highest content of polyphenol oxidase with the same average of $0.58 \mathrm{mg} / \mathrm{g}$ fresh weight $/ \mathrm{min}$. In case of peroxidase activity, Giza $716 \mathrm{cv}$. had the first grade with an average of $0.69 \mathrm{mg} / \mathrm{g}$ fresh weight/min followed by Sakha 1 and Sakha 4 cultivars with the same average (0.66). $\mathrm{Fe}, \mathrm{Mn}$ and $\mathrm{Zn}$ caused significant excess from one hand for leaves peroxidase and polyphenol oxidase activities and on the other hand for seeds carbohydrates and total protein compared to Mancozeb and control treatments. $\mathrm{Zn}$ had the highest values with averages of $0.72,0.62,53.40 \%$ and $24.87 \%$ respectively.

Foliar treatment of broad bean with $\mathrm{Zn}$ caused significant increases in the contents of photosynthetic pigments, soluble carbohydrates and soluble proteins greatly affected the activities of amylases, proteases, 3 catalases and peroxidases (Sharaf et al., 2009). 
Amina I. El-Shafey, et al.,

Table (4): Effect of cultivars, foliar application treatments and their interaction on leaf chlorophyll $\mathrm{a}, \mathrm{b}$ and $\mathrm{a}+\mathrm{b}$ contents $(\mathrm{mg} / \mathrm{g}$ leaves fresh weight) during two successive seasons after 90 days from sowing under field conditions.

\begin{tabular}{|c|c|c|c|c|c|c|c|}
\hline \multicolumn{2}{|c|}{ Parameter } & \multicolumn{2}{|c|}{ Chlorophyll a } & \multicolumn{2}{|c|}{ Chlorophyll b } & \multicolumn{2}{|c|}{ Chlorophyll $\mathbf{a}+\mathbf{b}$} \\
\hline \multicolumn{2}{|l|}{ Factor } & $2017 / 2018$ & $2018 / 2019$ & $2017 / 2018$ & 2018/2019 & $2017 / 2018$ & 2018/2019 \\
\hline \multicolumn{8}{|c|}{ Cultivar ( C ) } \\
\hline \multicolumn{2}{|l|}{ Sakha 1} & 0.80 & $0.86^{b}$ & $0.44^{b}$ & $0.46^{b}$ & 1.24 & $1.32^{b}$ \\
\hline \multicolumn{2}{|l|}{ Sakha 4} & 0.79 & $0.90^{\mathrm{a}}$ & $0.45^{a b}$ & $0.47^{a b}$ & 1.24 & $1.37^{\mathrm{a}}$ \\
\hline \multicolumn{2}{|l|}{ Giza 716} & 0.80 & $0.90^{a}$ & $0.47^{a}$ & $0.49^{a}$ & 1.27 & $1.39^{a}$ \\
\hline \multicolumn{8}{|c|}{ Treatment ( $\mathrm{T}$ ) } \\
\hline \multicolumn{2}{|l|}{$\mathrm{Fe}$} & $0.93^{a}$ & $0.93^{a}$ & $0.49^{a}$ & $0.53^{a}$ & $1.34^{\mathrm{a}}$ & $1.46^{a}$ \\
\hline \multicolumn{2}{|l|}{ Mn } & $0.81^{b}$ & $0.94^{\mathrm{a}}$ & $0.49^{a}$ & $0.50^{\mathrm{a}}$ & $1.31^{\mathrm{ab}}$ & $1.44^{\mathrm{a}}$ \\
\hline \multicolumn{2}{|l|}{ Zn } & $0.81^{b}$ & $0.93^{a}$ & $0.48^{a}$ & $0.50^{\mathrm{a}}$ & $1.28^{b}$ & $1.43^{a}$ \\
\hline \multicolumn{2}{|c|}{ Mancozeb } & $0.78^{c}$ & $0.84^{b}$ & $0.41^{b}$ & $0.44^{b}$ & $1.18^{c}$ & $1.29^{b}$ \\
\hline \multicolumn{2}{|l|}{ Control } & $0.75^{c}$ & $0.79^{c}$ & $0.38^{b}$ & $0.40^{c}$ & $1.13^{d}$ & $1.20^{c}$ \\
\hline \multicolumn{8}{|c|}{ Interaction (CXT) } \\
\hline \multirow{5}{*}{ Sakha 1} & $\mathrm{Fe}$ & 0.86 & 0.89 & 0.48 & 0.51 & 1.34 & 1.40 \\
\hline & Mn & 0.80 & 0.90 & 0.49 & 0.48 & 1.29 & 1.38 \\
\hline & $\mathrm{Zn}$ & 0.81 & 0.89 & 0.46 & 0.49 & 1.27 & 1.38 \\
\hline & Mancozeb & 0.79 & 0.82 & 0.38 & 0.41 & 1.18 & 1.23 \\
\hline & Control & 0.76 & 0.79 & 0.36 & 0.41 & 1.12 & 1.20 \\
\hline \multirow{5}{*}{ Sakha 4} & $\mathrm{Fe}$ & 0.83 & 0.93 & 0.50 & 0.53 & 1.33 & 1.46 \\
\hline & Mn & 0.79 & 0.94 & 0.49 & 0.50 & 1.28 & 1.45 \\
\hline & $\mathrm{Zn}$ & 0.82 & 0.95 & 0.47 & 0.49 & 1.28 & 1.44 \\
\hline & Mancozeb & 0.77 & 0.86 & 0.40 & 0.45 & 1.17 & 1.31 \\
\hline & Control & 0.74 & 0.81 & 0.39 & 0.40 & 1.13 & 1.21 \\
\hline \multirow{5}{*}{ Giza 716} & $\mathrm{Fe}$ & 0.86 & 0.98 & 0.49 & 0.54 & 1.36 & 1.52 \\
\hline & Mn & 0.85 & 0.97 & 0.50 & 0.51 & 1.35 & 1.48 \\
\hline & Zn & 0.80 & 0.94 & 0.50 & 0.52 & 1.30 & 1.46 \\
\hline & Mancozeb & 0.77 & 0.85 & 0.44 & 0.47 & 1.20 & 1.32 \\
\hline & Control & 0.74 & 0.77 & 0.39 & 0.40 & 1.13 & 1.18 \\
\hline \multicolumn{2}{|c|}{ LSD 5\% Cultivar ( C) } & NS & 0.03 & 0.02 & 0.03 & NS & 0.04 \\
\hline \multicolumn{2}{|c|}{ LSD 5\%Treatment (T) } & 0.03 & 0.03 & 0.03 & 0.03 & 0.05 & 0.05 \\
\hline \multicolumn{2}{|c|}{ LSD 5\% C x T } & 0.06 & 0.06 & 0.05 & 0.06 & 0.08 & 0.08 \\
\hline
\end{tabular}

Means in the same column followed by the same letter (s) are not significant according to L.S.D 0.05 values. 
Table (5): Effect of cultivars, foliar application treatments and their interaction on seed content of total carbohydrates and protein (\%), peroxidase and polyphenol oxidase activities $(\mathrm{mg} / \mathrm{g}$ leaves fresh weight/min) in the second season 2018/2019.

\begin{tabular}{|c|c|c|c|c|c|}
\hline \multicolumn{2}{|c|}{ Parameter } & \multirow{3}{*}{$\begin{array}{c}\text { Total } \\
\text { Carbohydrates (\%) }\end{array}$} & \multirow{3}{*}{$\begin{array}{c}\text { Total } \\
\text { protein(\%) }\end{array}$} & \multirow{3}{*}{$\begin{array}{c}\text { Peroxidase } \\
\text { Activity }\end{array}$} & \multirow{3}{*}{$\begin{array}{c}\text { Polyphenol } \\
\text { oxidase Activity }\end{array}$} \\
\hline$F$ & ctor & & & & \\
\hline \multicolumn{2}{|c|}{ Cultivar ( C ) } & & & & \\
\hline \multicolumn{2}{|l|}{ Sakha 1} & 5225 & 23.62 & $0.66^{b}$ & 0.57 \\
\hline \multicolumn{2}{|l|}{ Sakha 4} & 52.40 & 24.08 & $0.66^{b}$ & 0.58 \\
\hline \multicolumn{2}{|l|}{ Giza 716} & 51.72 & 23.86 & $0.69^{a}$ & 0.58 \\
\hline \multicolumn{6}{|c|}{ Treatment ( $\mathrm{T}$ ) } \\
\hline \multicolumn{2}{|l|}{$\mathrm{Fe}$} & $52.79^{a b}$ & $24.68^{a}$ & $0.70^{a}$ & $0.60^{a}$ \\
\hline \multicolumn{2}{|l|}{ Mn } & $52.60^{\mathrm{ab}}$ & $24.48^{a}$ & $0.69^{a}$ & $0.61^{a}$ \\
\hline \multicolumn{2}{|l|}{$\mathrm{Zn}$} & $53.40^{a}$ & $24.87^{a}$ & $0.72^{a}$ & $0.62^{a}$ \\
\hline \multicolumn{2}{|c|}{ Mancozeb } & $51.20^{b c}$ & $22.91^{b}$ & $0.64^{b}$ & $0.56^{b}$ \\
\hline \multicolumn{2}{|l|}{ Control } & $50.61^{c}$ & $22.32^{b}$ & $0.59^{c}$ & $0.48^{c}$ \\
\hline \multicolumn{6}{|c|}{ Interaction (CxT) } \\
\hline \multirow{5}{*}{ Sakha 1} & $\mathrm{Fe}$ & 52.36 & 24.48 & 0.71 & 0.60 \\
\hline & Mn & 53.01 & 23.78 & 0.69 & 0.63 \\
\hline & $\mathrm{Zn}$ & 54.13 & 24.64 & 0.72 & 0.62 \\
\hline & Mancozeb & 51.39 & 23.06 & 0.61 & 0.55 \\
\hline & Control & 50.34 & 22.32 & 0.59 & 0.46 \\
\hline \multirow{5}{*}{ Sakha 4} & $\mathrm{Fe}$ & 53.80 & 24.55 & 0.70 & 0.59 \\
\hline & Mn & 52.72 & 24.91 & 0.69 & 0.59 \\
\hline & $\mathrm{Zn}$ & 52.84 & 25.02 & 0.72 & 0.61 \\
\hline & Mancozeb & 51.60 & 23.23 & 0.62 & 0.58 \\
\hline & Control & 51.03 & 22.69 & 0.59 & 0.51 \\
\hline \multirow{5}{*}{ Giza 716} & $\mathrm{Fe}$ & 52.20 & 25.22 & 0.73 & 0.61 \\
\hline & Mn & 51.34 & 24.74 & 0.70 & 0.62 \\
\hline & $\mathrm{Zn}$ & 53.24 & 24.95 & 0.72 & 0.62 \\
\hline & Mancozeb & 50.60 & 22.45 & 0.71 & 0.56 \\
\hline & Control & 50.48 & 21.95 & 0.59 & 0.48 \\
\hline \multicolumn{2}{|c|}{ LSD 5\% Cultivar ( C ) } & NS & NS & 0.02 & NS \\
\hline \multicolumn{2}{|c|}{ LSD 5\% Treatment (T) } & 1.85 & 0.77 & 0.03 & 0.03 \\
\hline \multicolumn{2}{|c|}{ LSD 5\% C x T } & 3.21 & 1.05 & 0.05 & 0.05 \\
\hline
\end{tabular}

Means in the same column followed by the same letter (s) are not significant according to L.S.D 0.05 values. 
In this respect, El Sayed et al., (2012) illustrated that spraying with micronutrients significantly increased the concentration of total carbohydrates and total protein in green seeds of pea plants compared with control plants. In this connection, Elwakil et al., (2016) reported that $\mathrm{Zn}$ and $\mathrm{Fe}$ in the form of seed soaking or foliar spraying increased faba bean total protein in seeds. Also, Radwan and Tawfik, (2004) showed that the positive effect of micronutrients on chemical contents may be due to their involvement in one or more of important biological functions such as synthesis of chlorophyll, electron transport system, oxidation-reduction reactions, protein synthesis and degradation. On the other hand, El-Gebaly et al., (2003) pointed out that, treatment flax plants with $\mathrm{Zn}$ insignificantly affected the activities of peroxidase and polyphenol oxidases enzymes.

In concern to the interaction, the statistical analysis showed that the differences between the values of total carbohydrates, total protein, peroxidase and polyphenol oxidase are significant. The use of $\mathrm{Fe}, \mathrm{Mn}$ and $\mathrm{Zn}$ in the three cultivars led to significantly increase of total carbohydrates, total protein and peroxidase and phenol oxidase activities compared to mancozeb and control treatments.

\section{6- Effect of cultivars, foliar} application treatments and their interaction on chocolate spot disease severity in 2017/2018 and 2018/2019 growing season:

Data presented in Table (6) show the percentages of chocolate spot disease severity of faba bean cultivars which were sprayed with chelated $\mathrm{Fe}, \mathrm{Mn}$ and $\mathrm{Zn}$ after 75, 90 and 105 days during two successive seasons. The results exhibit that disease severity differed between the three tested cultivars and it increased with increasing time. Data of the first season show that Sakha $1 \mathrm{cv}$. had the least disease severity after $\mathbf{9 0}$ days from sowing with an average of $4.78 \%$. Generally Sakha $1 \mathrm{cv}$. had the least general mean of disease severity followed by Giza 716 and Sakha 4 cultivars with $4.89,5.01$ and $5.07 \%$, respectively. Statistically, the differences between the values of cultivars disease severity are not significant except in case of 90 days after sowing. In case of the second season, the insignificant differences were obtained for disease severity in 90 and 105 days. Disease severity after 75 and 105 days looks like that in the first season but in case of 90 days the three cultivars differed in its arrangement and Giza $716 \mathrm{cv}$. had the least general mean $4.79 \%$.

These results are in agreement with the findings of El-Sayed et al., (2011) who mentioned that Giza 716 and Sakha 1 were the lowest infection with $B$. fabae compared to the other tested cultivars. Huber and Haneklaus (2007) mentioned that disease resistance is genetically controlled, but mediated through physiological and biochemical processes interrelated with the nutritional status of the plant or pathogen. Also, Yitayih and Azmeraw (2018) reported that the differences among faba bean cultivars for chocolate spot disease incidence and severity may be due to the genetic variation between cultivars to the infection.

From the same Table data appear that foliar spraying of $\mathrm{Fe}, \mathrm{Mn}, \mathrm{Zn}$ and mancozeb in the first season decreased chocolate disease severity compared to the control treatment. Mancozeb had the best effect in reducing the disease severity more than the other treatments with general mean of $4.05 \%$ followed by $\mathrm{Fe}, \mathrm{Zn}$ and $\mathrm{Mn}$ with general means of $4.61,4.63$ and $5.05 \%$, respectively. In 
case of the second season the results are close to that of the first season, where Mancozeb had the best effect followed by $\mathrm{Zn}$, Fe and $\mathrm{Mn}$ with general means 3.98, 4.66, 4.73 and $4.84 \%$, respectively.
As for the interaction effect data indicated that spraying Sakha 4 and Sakha 1 cultivars with mancozeb significantly reduced the disease severity in both seasons with general means of 4.03 and $3.91 \%$ respectively.

Table (6): Effect of cultivars, foliar application treatments and their interaction on chocolate spot disease severity \% caused by Botrytis fabae during two successive seasons under field conditions.

\begin{tabular}{|c|c|c|c|c|c|c|c|c|c|}
\hline \multicolumn{2}{|c|}{ Season } & \multicolumn{4}{|c|}{$2017 / 2018$} & \multicolumn{4}{|c|}{$2018 / 2019$} \\
\hline \multirow{2}{*}{\multicolumn{2}{|c|}{ Factor days }} & \multicolumn{8}{|c|}{ Days from sowing } \\
\hline & & 75 & 90 & 105 & Mean & 75 & 90 & 105 & Mean \\
\hline \multicolumn{10}{|c|}{ Cultivar ( C ) } \\
\hline \multicolumn{2}{|c|}{ Sakha 1} & 3.11 & $4.78^{b}$ & 6.79 & 4.89 & $3.03^{b}$ & 5.04 & 6.84 & 4.97 \\
\hline \multicolumn{2}{|l|}{ Sakha 4} & 3.14 & $5.51^{a}$ & 6.57 & 5.07 & $3.14^{b}$ & 5.04 & 6.59 & 4.92 \\
\hline \multicolumn{2}{|l|}{ Giza 716} & 3.06 & $5.38^{a}$ & 6.59 & 5.01 & $2.87^{\mathrm{a}}$ & 4.79 & 6.84 & 4.84 \\
\hline \multicolumn{10}{|c|}{ Treatment( T ) } \\
\hline \multicolumn{2}{|c|}{ 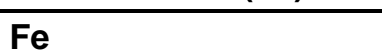 } & $2.76^{b c}$ & $4.85^{b c}$ & $6.21^{b c}$ & 4.61 & $2.84^{b c}$ & $4.73^{b c}$ & $6.61^{b}$ & 4.73 \\
\hline \multicolumn{2}{|l|}{ Mn } & $3.24^{b}$ & $5.35^{b}$ & $6.55^{b}$ & 5.05 & $2.87^{b c}$ & $4.78^{b}$ & $6.88^{b}$ & 4.84 \\
\hline \multicolumn{2}{|l|}{$\mathrm{Zn}$} & $2.85^{b c}$ & $4.94^{b c}$ & $6.11^{b c}$ & 4.63 & $3.04^{b}$ & $5.07^{b}$ & $5.88^{c}$ & 4.66 \\
\hline \multicolumn{2}{|c|}{ Mancozeb } & $2.52 \mathrm{c}$ & $4.27^{c}$ & $5.35^{c}$ & 4.05 & $2.67^{c}$ & $4.44^{c}$ & $4.82^{d}$ & 3.98 \\
\hline \multicolumn{2}{|c|}{ Control } & $4.15^{a}$ & $6.71^{a}$ & $9.01^{a}$ & 6.62 & $3.66^{\mathrm{a}}$ & $5.76^{a}$ & $9.59^{a}$ & 6.33 \\
\hline \multicolumn{10}{|c|}{ Interaction (CxT) } \\
\hline \multirow{5}{*}{ Sakha 1} & $\mathrm{Fe}$ & 2.69 & 3.69 & 6.78 & 4.39 & 2.82 & 4.69 & 7.76 & 5.09 \\
\hline & Mn & 3.06 & 5.18 & 6.55 & 4.93 & 2.89 & 4.82 & 6.93 & 4.88 \\
\hline & $\mathrm{Zn}$ & 2.81 & 4.68 & 5.91 & 4.47 & 3.19 & 5.31 & 5.68 & 4.73 \\
\hline & Mancozeb & 2.58 & 3.94 & 5.68 & 4.07 & 2.59 & 4.32 & 4.82 & 3.91 \\
\hline & Control & 4.42 & 6.41 & 9.01 & 6.61 & 3.64 & 6.05 & 9.01 & 6.23 \\
\hline \multirow{5}{*}{ Sakha 4} & $\mathrm{Fe}$ & 2.81 & 5.43 & 5.93 & 4.72 & 3.04 & 5.06 & 6.03 & 4.71 \\
\hline & Mn & 3.43 & 5.19 & 6.67 & 5.10 & 2.82 & 4.69 & 6.82 & 4.78 \\
\hline & $\mathrm{Zn}$ & 2.94 & 5.19 & 6.40 & 4.84 & 3.04 & 5.07 & 6.03 & 4.71 \\
\hline & Mancozeb & 2.57 & 4.44 & 5.07 & 4.03 & 2.82 & 4.69 & 4.69 & 4.07 \\
\hline & Control & 3.93 & 7.29 & 8.77 & 6.66 & 4.00 & 5.68 & 9.38 & 6.35 \\
\hline \multirow{5}{*}{ Giza 716} & $\mathrm{Fe}$ & 2.77 & 5.44 & 5.93 & 4.71 & 2.67 & 4.44 & 6.05 & 4.39 \\
\hline & Mn & 3.23 & 5.68 & 6.42 & 5.11 & 2.89 & 4.82 & 6.90 & 4.87 \\
\hline & $Z n$ & 2.81 & 4.94 & 6.03 & 4.59 & 2.89 & 4.82 & 5.93 & 4.55 \\
\hline & Mancozeb & 2.40 & 4.44 & 5.31 & 4.05 & 2.59 & 4.32 & 4.94 & 3.95 \\
\hline & Control & 4.10 & 6.42 & 9.26 & 6.59 & 3.33 & 5.56 & 10.37 & 6.42 \\
\hline \multicolumn{2}{|c|}{ LSD 5\% Cultivar ( C ) } & NS & 0.59 & NS & & 0.22 & NS & NS & \\
\hline \multicolumn{2}{|c|}{ LSD 5\% Treatment (T) } & 0.66 & 0.77 & 0.76 & & 0.28 & 0.46 & 0.51 & \\
\hline \multicolumn{2}{|c|}{ LSD 5\% C x T } & 1.14 & 1.33 & 1.32 & & 0.49 & 0.80 & 0.88 & \\
\hline
\end{tabular}

Means in the same column followed by the same letter (s) are not significant according to L.S.D 0.05 values. 
The results are in harmony with that reported by Elwakil et al., (2016) who stated that all tested combinations of salicylic acid, $\mathrm{Zn}$ and $\mathrm{Fe}$ decreased chocolate spot severity. Generally, nutrient sufficiency may provide a general form of disease resistance by maintaining a high level of inhibitory compounds in tissue or quick response to invasion by a pathogen. Mn has an important role in lignin and suberin biosynthesis (Vidhyasekaran, 1997) which are important biochemical barriers to fungal pathogen invasion (Yousef et al., 2013) through activation of several enzymes of the Shikimic acid and phenylpropanoid pathway (Marschner, 1995), since they are phenolic polymers resistant to enzymatic degradation (Agrios, 2005). Also, it inhibits the induction of aminopeptidase, an enzyme which supplies essential amino acids for fungal growth and pectin methylesterase, a fungal enzyme that degrades host cell walls. Cakmak (2000) stated that $\mathrm{Zn}$ is involved in membrane protection against oxidative damage through the detoxification of superoxide radicals. Fe is a component of peroxidase and stimulates other enzymes involved in the biosynthetic pathway. Also, it can activate enzymes that are involved in the infection of the host by the pathogen or the defense, which is why opposite effects were found (Graham and Webb, 1991).

Data illustrated in Figure 1 show the reduction of chocolate spot disease severity in the foliar spraying treatments compared to control treatment (infected only). In the first season Mancozeb had the best effect in reducing the disease severity followed by $\mathrm{Fe}, \mathrm{Zn}$ and $\mathrm{Mn}$ with averages of $38.82,30.36,30.06$ and $23.71 \%$ compared to the control treatment, respectively. The results of the second season Mancozeb followed by $\mathrm{Zn}, \mathrm{Fe}$ and $\mathrm{Mn}$ with averages of $\mathbf{3 7 . 1 2}$, $26.38,25.28$ and $23.54 \%$, respectively.

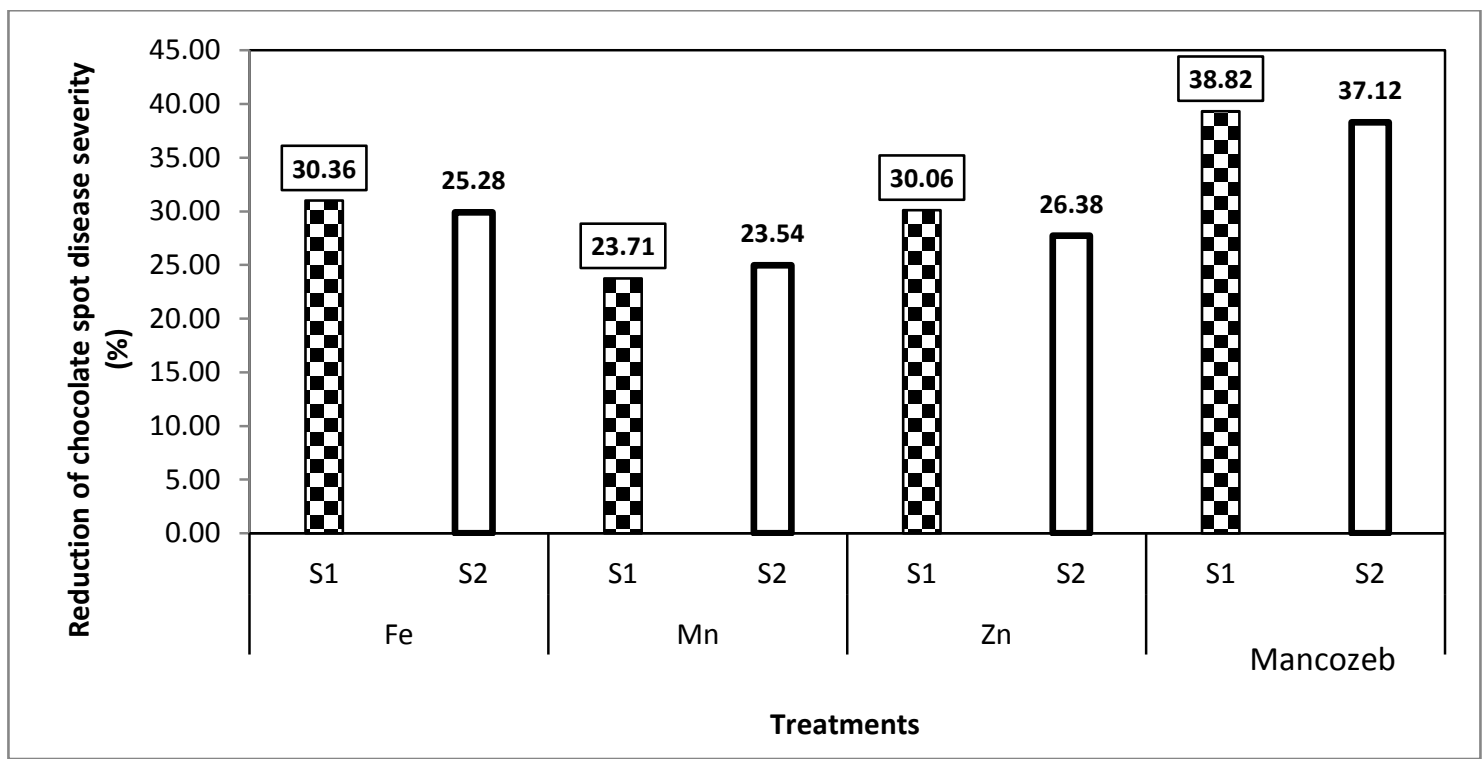

Figure (1): The reduction of chocolate spot disease severity in the foliar spraying treatments compared to control treatment $(\mathrm{S} 1=2017 / 2018$ and $\mathrm{S} 2=$ 2018/2019). 
7- The relationship between the activity of defense - related enzymes (peroxidase and polyphenol oxidase) and chocolate spot disease severity on the sprayed faba bean cultivars:

Peroxidase play active role in cell wall toughening and production of toxic secondary metabolites and its simultaneous oxidant and antioxidant properties make it an important factor in the defense response of plants to a variety of stresses (Idrees et al., 2011). Oxidation of phenols by polyphenol oxidase leads to formation of quinones and free radicals that can activate enzymes, which form a part of the metabolic processes acting against different stresses (Bhonwong et al., 2009). When the plant found a suitable amount of microelements such as $\mathrm{Fe}, \mathrm{Mn}$ and $\mathrm{Zn}$ it used it as alternative defense materials and this consider a basic reason in the decrease of plant enzymes defense such as peroxidase and polyphenol oxidase under higher disease infections.

Data presented in Figure 2 (A, B and C) clear that there were negative association between disease severity of chocolate spot and peroxidase and polyphenol oxidase in all cases. The association between disease severity and peroxidase activity for the three cultivars was significantly negative with correlation coefficient of $r=-0.834^{\star}$ while, the association between disease severity and polyphenol oxidase activity for the same three cultivars was insignificantly negative and very weak with correlation coefficient of $r=-0.243$ (Figure 2-A). The high and/or moderate negative association between disease severity and peroxidase and polyphenol oxidase activities were presented over all treatments where the correlation coefficients were $r=-0.622$ and $r=-$ $0.808^{\star}$ for peroxidase and polyphenol oxidase, respectively (Figure 2-B).With respect to the relationship between disease severity and peroxidase and polyphenol oxidase for both cultivars and treatments data presented in Figure (2-C) indicated that there were significant and highly significant association between disease severity and peroxidase and polyphenol oxidase where the correlation coefficient were $r=-0.496^{\star}$ and $r=$ $0.626^{*}$, respectively. These results are in harmony with the findings of Kumari and Vengadaramana (2017) who reported that plants enhance defense responses by inducing activity of a broad spectrum of defense enzymes which are pathogenesis - related (PR) proteins, namely peroxidase, $\beta-1,3$ - glucanase, chitinase, polyphenol oxidase and phenylalanine ammonia lyase which slow the rate of disease spread. Also, EI Ghanam et al., (2018) mentioned that with increasing the activity of peroxidase and polyphenol oxidase, the disease severity of powdery mildew in squash decreased. Also, when peroxidase level increases due to the induced systemic resistance (Prasannath et al., 2014), quick synthesis of reactive oxygen derivatives by oxidative burst lead to cell death and inhibits pathogenic activities (Almagro et al., 2009). In this respect, Lai et al., (2007) mentioned that most of the biotic and abiotic stresses lead to an increase in the production of reactive oxygen species (ROS) which in high density, hurt cells lipids, proteins and nucleic acids and finally stop the natural metabolism of plant. Plants protect themselves from cytotoxic effects of these ROS with the help of antioxidant enzymes such as peroxidase, polyphenol oxidase, catalase and superoxide dismutase induced in plants in response to the stress (He et al., 2011 and Rani and Jyothsna, 2012). 
Amina I. El-Shafey, et al.,
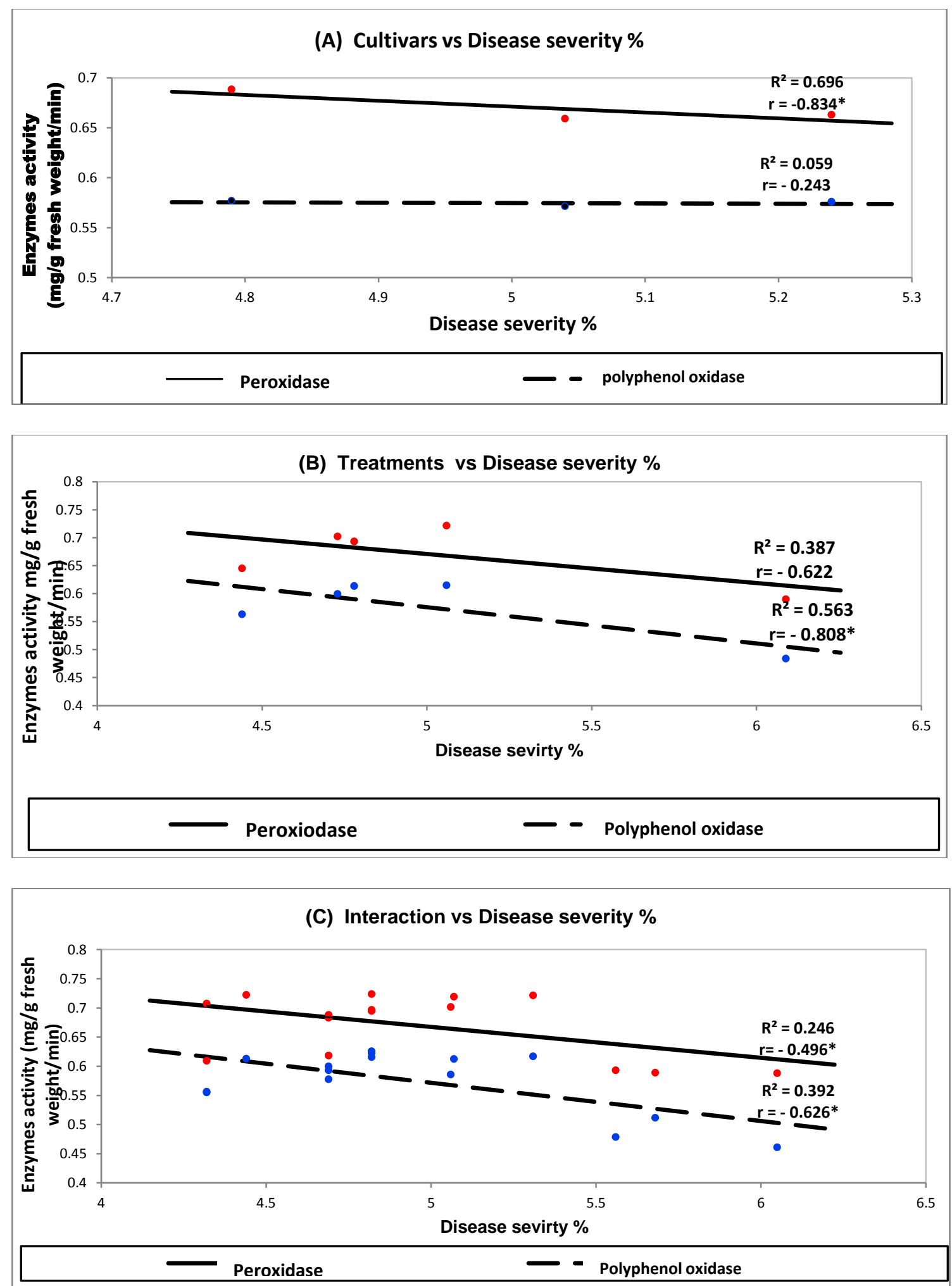

Figure 2: Linear regression of peroxidase and polyphenol oxidase activities $(\mathrm{mg} / \mathrm{g}$ leaves fresh weight $/ \mathrm{min}$ ) by chocolate spot disease severity \% ( $A=$ faba bean cultivars, $B=$ treatments and $C=$ the interaction between cultivars $x$ treatments). 
Peroxidase oxidizes phenolics to quinones and generates hydrogen peroxide. It is antimicrobial and also releases highly reactive free radicals and further increases the rate of polymerization of phenolic compounds into lignin-like substances. These substances are then deposited in cell walls and papillae and hinder the further growth and development of the pathogen (Agrios, 2005). In addition, a large number of toxic phytoalexins can be derived from phenolic compounds (Orcutt and Nilsen, 2000). Also, Alfred (2006) reported that polyphenol oxidases participate in the oxidation of aromatic substrates and dihydroxphenolic compounds in the presence of oxygen in host tissues, producing quinones that are toxic to pathogens

\section{REFERENCES}

Abd El-azeem, K. S., E. H. El-Harty, M. H. Ammar and S. S. Alghamdi (2014). Evaluation of faba bean (Vicia faba L.) performance under various micronutrients foliar applications and plant spacing. Life Sci. J., 11(10): 1298-1304.

Abd-El Hamid, A. M. and S. H. Sarhan (2008). Response of faba bean yield to inorganic, organic, $\mathrm{N}$-fertilizers and their combination with some compounds as foliar application on growth, yield and mineral composition. J. Agric. Sci. Mansoura, Univ., 33: 195-204.

Agegnehu, G., A. Ghizaw and W. Sinebo (2006). Yield performance and landuse efficiency of barley and faba bean mixed cropping in Ethiopian highlands. Eur. J. Agron., 25: 202-207.

Agegnehu, G. and R. Fessehaie (2006). Response of faba bean to phosphate fertilizer and weed control on nitisols of Ethiopian highlands. Italian J. Agron., 2: 281-290.

Agrios, N.G. (2005). Plant Pathology, 5th ed., Elsevier-Academic Press., p. 635.

Alfred, M. M. (2006). Polyphenol oxidases in plants and fungi: Going places? A review. Phytochemistry., 67:23182331.

Alloway, B. (2004). Zinc in soils and crop nutrition. Areas of the world with zinc deficiency problems. Available at: http://www. zinc-crops. org/Crops/Alloway-all

Almagro, L. L., R. A. Gomez, S. BelchiNavarro, R. Bru, B. A. Ros and M. A. Pedreno (2009). Plants defend themselves against pathogen attack by activating a multicomponent defense response. J. Exp. Bot., 60 (2):377-390.

Amako, A., K. Chen and K. Asada (1994). Separate assays specific for ascorbate peroxidase and gauiacol peroxidase and for the chloroplastic and cytosilic isoenxymes of ascorbate peroxidase in plants. Plant Cell Physiol., 35:497-504.

AOAC (1988). Official Methods of Analysis $21^{\text {st }}$ Ed., Association of Official Agricultural Chemists, Washington, D. C., USA.

Bameri, M., R. Abdolshahi, G. Mohammadi-Nejad, K. Yousefi and S. M. Tabatabaie (2012). Effect of different microelement treatment on wheat (Triticum aestivum) growth and yield. Inter. Res. J. of Appl. and Bas. Sci., (3)1: 219-223.

Bernier, C. C., S. B. Hanounik, M. M. Hussein and H. A. Mohamed (1984). 'Rating scale for faba bean diseases in Nile valley. ICARDA Inform. Bull. No. 3.p. 37.

Bernier, C. C., S. B. Hanounik,, M. M. Hussein and H. A. Mohamed (1993). 
Field manual of common bean diseases in the Nile Valley. ICARDA Inform. Bull. 3: 40.

Bhonwong , A. , M. J. Stout, J. Attajarusit and P. Tantasawat (2009). Defensive role of tomato polyphenol oxidases against cotton bollworm (Helicoverpa armigera) and beet armyworm (Spodoptra exigua). J. Chem. Ecol., 35: 28-38.

Boubekeur, S. B., D. Mahiout, I. E. Benzohra and M. Y. Benkada (2012). Antagonism of three Trichoderma species against Botrytis fabae and $B$. cinerea, the causal agents of chocolate spot of faba bean (Vicia faba L.) in Algeria. World Appl. Sci. J., 17 (3): 278-283.

Bozorgi, H. A., E. Azarpour and M. Moradi (2011). The effects of bio, mineral nitrogen fertilization and foliar zinc spraying on yield and yield components of faba bean. World Appl. Sci. J., 13(6): 1409-1414.

Cakmak I. M. (2000). Possible roles of zinc in protecting plant cells from damage by reactive oxygen species, New Phytol., 146: 185-205.

Dubois, M., K. A. Gilles, J. R. Hamilton and F. Smith (1956). Colorimetric method for determination of sugar and related substance. Annal. Chem., 28: 350-356.

Dutta, S., P. P. Ghosh, A. K. Ghorai, M. de Roy and S. Das (2017). Micronutrients and plant disease suppression. Fertili. Environ. News., 3 (2): 4-8.

El-Bramawy, M. A. S. and O. A. Abdul Wahid (2005). Faba bean sources of resistance to chocolate and spot diseases, earliness and seed yield. The $7^{\text {th }}$ ACSS Conf.,5-9 Sept., Uganda., (7): 359-562.

El-Desuki , M., M. M. Hafez, A. R. Mahmoud and F. S. Abd-El-Ai (2010). Effect of organic and bio-fertilizers on the plant growth, green pod yield and quality of pea. Introd. J. Acad. Res., 2(1): 87.

El-Fiki, S. F., S. A. El-Shekha and E. M. K. Behiry (2008). Impact of seed coating with yield. Zagazig J. Agric. Res., 35: 531-541.

El-Gebaly, A. H., E. H. Omran, and N. A. Ahsry (2003). Response of flax plants to foliar application of organic acids and zinc. Egypt. J. Appl. Sci., 18(12): 337-355.

El-Ghanam, Abeer A., M. M. H. Rahhal, M. A. Al-Saman and Entsar K. A. Khattab (2018). Alternative safety methods for controlling powdery mildew in squash under field conditions. Asian J. Adv. Agric. Res., 7(1): 1-21.

El-Sallami, I. H. and M. M. Gad (2005). Growth and flowering response of New York aster (Aster novibelgii L.) to a slow release fertilizer and foliar applied zinc. Assuit J. Agric. Sci., 36(2): 121-136.

El-Sayed, A. Sahar, Rania Z. El-Shennawy and A. I. Ismail (2011). Fungicidal management of chocolate spot of faba bean and assessment of yield losses due to the disease. Ann. Agric. Sci., 56: 27-35.

El Sayed, H. E. A., A. Amen, A. H. ElMorsy and M. H. Tolba (2012). Effects of foliar spraying with microelements and different fertilizer source on quality and yield of Pism sativum $\mathrm{L}$. Plant Inter. Res. J. of Agric. Sci. and Soil., 2(1): 17-24.

Elwakil, M. A., M. A. Abass, M. A. ElMetwally and Mona S. Mohamed (2016). Green chemistry for inducing resistance against chocolate spot disease of faba bean. J. Environ. Sci. Technol., 9 (1): 170-187.

Fernandes, D. S., R. R. P. Soratto, S. M. Kulczynski, G. A. Biscaro and C.J. dos Reis (2007). Yield and physiological 
quality of common bean seeds as affected by manganese foliar application. Pesq. Agropec. Bras. Brasilia., 42: 419-426.

Ghasemian, V., A. Ghalavand, A. S. Zadeh and A. Pirzad (2010). The effect of iron, zinc and manganese on quality and quantity of soybean seed. J. Phytol., 2 (11): 73-79.

Gomez, K.A. and A.A. Gomez, (1984). Statistical Procedures for Agricultural Research. $2^{\text {nd }}$ ed., Wiley, New York.

Graham, D. R. and M. J. Webb (1991). Micronutrients and Disease Resistance and Tolerance in Plants, in: Mortvedt J., Cox F.R., Shuman L.M., Welch R.M. (Eds.), Micronutrients in Agriculture, $2^{\text {nd }}$ ed., Soil Science Society of America, Inc. Madison, Wisconsin, USA., pp. 329370.

He, J., F. Chen, S. Chen, G. Lv and Y. Deng (2011). Chrysanthemum leaf epidermal surface morphology and antioxidant and defense enzyme activity in response to aphid infestation. J. Plant Physiol., 168 (7): 687-693.

Huber, Don M. and S. Haneklaus (2007). Managing nutrition to control plant disease. Landbauforschung Völkenrode., 4 (57):313-322.

Ibrahim, M. E., M. A. Bekheta, A. ElMoursi and N. A. Gafar (2007). Improvement of growth and seed yield quality of Vicia faba L. plants as affected by application of some bioregulators. Aust. J. Basic and Appl. Sci., 1 (4): 657-666.

Idrees, M., N. Naeem, T. Aftab, M. M. Khan and A. Moinuddin (2011). Salicylic acid mitigates salinity stress by improving antioxidant defence system and enhances vincristine and vivblastine alkaloids production in periwinkle
(Catharanthus roseus L.). G. Don. Acta Physiol. Plant., 33 (3): 987-999.

Knany, R. E., R. H. Atia and A. S. M. ElSaady (2009). Response of faba bean to foliar spraying with humic substances and micronutrients. Alex. Sci. Exch. J., 453-460.

Kumari, Y. S. M. A. I. and A. Vengadaramana (2017). Stimulation of defense enzymes in tomato (Solanum lycopersicum L.) and chilli (Capsicum annuum L.) in response to exogenous application of different chemical elicitors. Univ. J. Plant Sci., 5 (1): 1015.

Kumawat, R. N., P. S. Rathore, N. S. Nathawat and M. Mahatma (2006). Effect of sulfur and iron on enzymatic activity and chlorophyll content of mung bean. J. Plant Nutr., 29: 14511467.

Lai, Q. X., Z. Y. Bao, Z. G. Zhu, Q. Q. Qian and B. Z. Mao (2007). Effect of osmotic stress on antioxidant enzymes activities in leaf discs of PsaG 12-IPT modified gerbera, J. Zhejiang Univ. Sci., B. 8 (7): 458-464.

Laware, S. L. and S. Raskar (2014). Influence of zinc oxide nanoparticles on growth, flowering and seed productivity in onion. Int. J. Curr. Microbiol. Appl. Sci., 3: 874-881.

Marschner, H. (1995). Mineral Nutrition of Higher Plants, 2nd ed., Academic Press, London, p. 889.

Mayer, A. M and E. Harel (1979). Polyphenol oxidases in plants. Phytochem., 18 (2):193-215.

Memari, Tabrizi E., V. Ahmadzadeh and N. Farjzadeh (2011). Priming effect of different times of maize seeds with nutrient elements in water stress on corn yield. Ann. Biol. Res., 2: 419-423.

Metzener, H., H. Rav and H. Senger (1965). Untersuchungen Zur Synchronisier-bakeit einzelner 
pigment. Mangol-mutanten von Chlorella. Planta, 65:186-194.

Noorka, I. R., S. Rehman, J. R. Haidry, I. Khaliq, S. Tabassam and M. Din (2009). Effect of water stress on physico-chemical properties of wheat (Triticum aestivum L.) Pak. J. Bot., 41(6): 2917-2924.

Omar, S. A. M., M. M. H. Rahhal and A. Zayed (1992). Influence of some microelements on disease severity of chocolate spot and rust, growth and yield of broad bean. Egypt. J. Appl. Sci., 7(11): 22-28.

Orcutt, D. M. and E. T. Nilsen (2000). Physiology of Plants Under Stress. John Wiley \& Sons, INC, New York., p. 342-344.

Pandey, N., G. C. Pathak and C. P. Sharma (2006). Zinc is critically required for pollen function and fertilization in lentil. J. Trace Elem. Med. Biol., 20: 89-96.

Potarzychi, J. and W. Grzebisz (2009). Effect of zinc foliar application on grain yield of maize and its yielding components. Plant soil Environ., 55 (12): 519-527.

Prasannath, K., D. M. De Costa and K. S. Hemachandra (2014). Quantification of peroxidase activity in chilli tissues grown under two crop protection systems across a temperature gradient. proceedings of the HETC symposium. $7^{\text {th }} \& 8^{\text {th }}$ July 2014. 102.

Radwan, E. A. and A. A. Tawfik (2004). Effect of sulphur, manganese and Zn on growth, yield and quality of potato (Solanum tuberoium L.). J. Agric. Sci. Mansoura Univ., 29(3): 1423-1431.

Rahhal, M. M. H. (1993). Effect of micronutrients on some fungal diseases of broad bean. Alex. Sci. Exch., 14 (1): 97-113.

Rani, P. U. and Y. Jyothsna (2012). Biochemical and enzymatic changes in rice plants as a mechanism of defense. Acta Physiol. Plant., 32 (4): 695-701.

Rewal, H. S. and J. S. Jhooty (1985). Differential response of wheat varieties to systemic fungicides applied to Ustilago tritici (Pers.). Rostr. Indian J. Agric. Sci., 55: 548549.

Romheld, V. and H. Marschner (1995). Genotypical differences among graminaceous species in release of phytoadiero phores and uptake of iron phytoauid phores. Plant Soil., 132: 147-153.

Sajedi, N. A. (2010). Effect of nutrients foliar application on agrophysiological characteristics of maize under water deficit stress. Nat. Sci. Biol.,2 (3): 3944.

Samuel, S., S. Ahmed, C. Fininsa, M. M. Abang and P. K. Sakhuja (2008). Survey of chocolate spot (Botrytis fabae) disease of faba bean (Vicia faba L.) and assessment of factors influencing disease epidemics in Northern Ethiopia. Crop Protec., 27: 1457-1463.

Sarkar, D., B. Mandal and M. C. Kundu (2007). Increasing use efficiency of boron fertilizers by rescheduling the time and methods of application for crops in India. Plant Soil., 301: 77-85.

Sharaf, A. M., I. I. Farghal and M. Sofy (2009). Response of broad bean and lupin plants to foliar treatment with boron and zinc. Aust. J. Basic and Appl. Sci., 3(3): 2226-2231.

Tekale, R. P., A. Guhey and K. Agrawal (2009). Impact of carbon, zinc and IAA on growth, dry matter accumulation and sink potential of pigeon pea (Cajanus cajan L.). Agric. Sci. Digest., 29 (4): 246-249.

Tharanathan, R. N. and S. Mahadevamma (2003). Grain legumes - a boon to 
human nutrition. Trends in Food and Science Technology., 14: 507-578.

Tobbal, Y. F. M. (2006). Physiological studies on the effect of some nutrients and growth regulators on plant growth and metabolism. Ph. D. Thesis, Fac. Sci. Al-Azhar Univ.

Torres, A. M., B. Roman, C. M. Avila, Z. Satovic, D. Rubiales, J. I. Sillero and M. T. Moreno (2006). Faba bean breeding for resistance against biotic stresses: towards application of marker technology. Euphytica., 147: 67-80.

Vidhyasekaran, P. (1997). Fungal Pathogenesis in Plants and Crops, Molecular Biology and Host Defense Mechanisms, Marcel Dekker, New York, USA., p. 568.
Wissuwa, M. A. M. Ismail and R. D. Graham (2008). Rice grain zinc concentrations as affected by genotype native soil-zinc availability, and zinc fertilization. Plant Soil., 37-48.

Yitayih, G. and Y. Azmeraw (2018). Evaluation of faba bean varieties against chocolate spot (Botrytis fabae Sard.) disease at Farta, South Gondar, Ethiopia. J. Crop Sci. Biotech., 21 (1): $35-41$.

Yousef, S. A. M., M. M. El-Metwally, S. A. Gaber and A. H. Al-Ghadir (2013). New strategy for managing damping-off and root rot disease of cucumber caused by Rhizoctonia solani by seed soaking in formula of antioxidant with micronutrients. J. Plant Pathol. Microbiol., 4. $10.4172 / 2157-7071-$ 1000196. 
Amina I. El-Shafey, et al.,

تأثير الرش ببعض العناصر الصغرى المخلبيه على النمو والانتاجية و شدة الاصابة

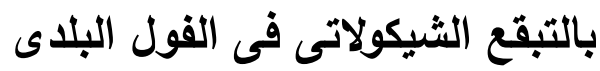

أمينة (براهيم الثافعى(1)، فايز السيد والى (2)، عادل الجارحى محمد (2)، محمد مجدى حمزة رحال(3) معال

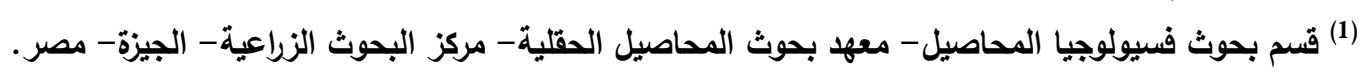

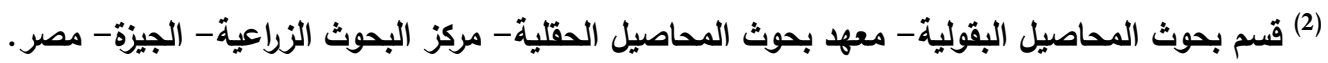

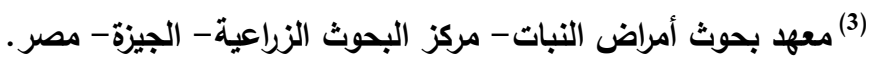

الملخص العربى

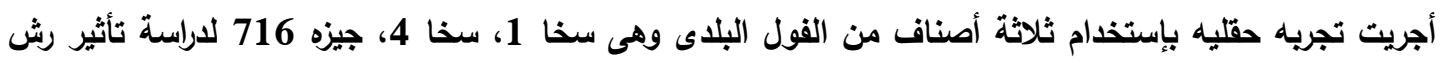

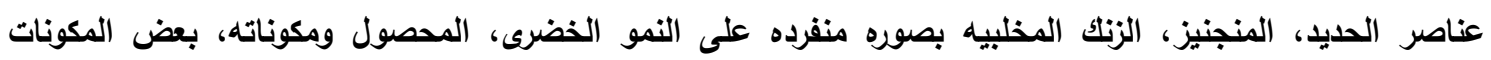

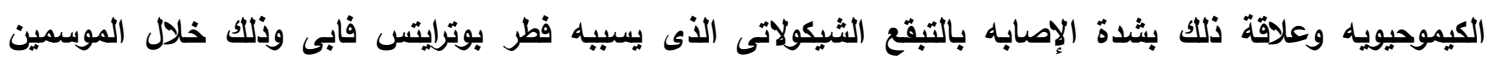

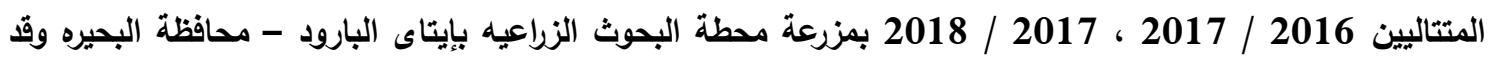

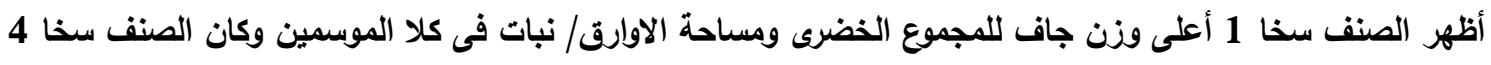

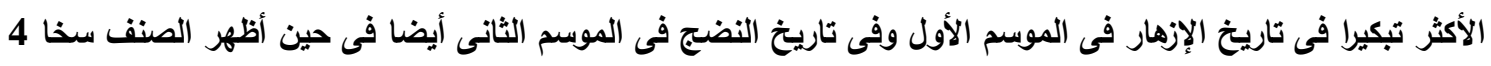

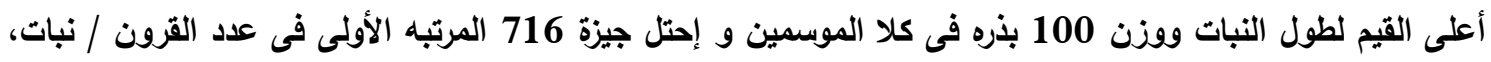

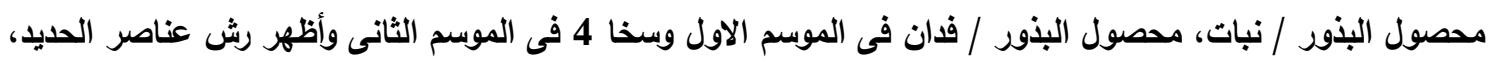

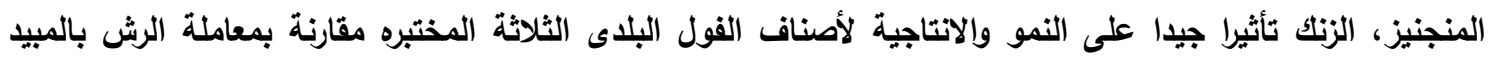

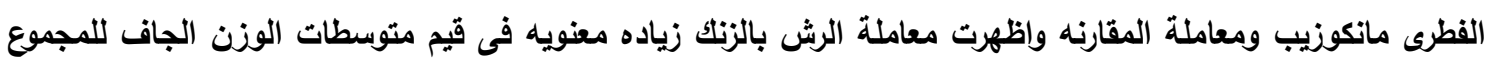

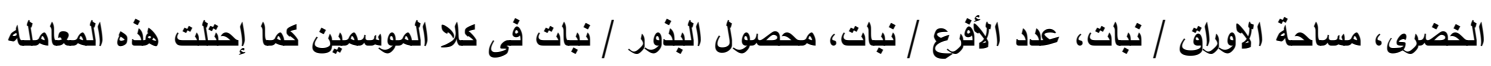

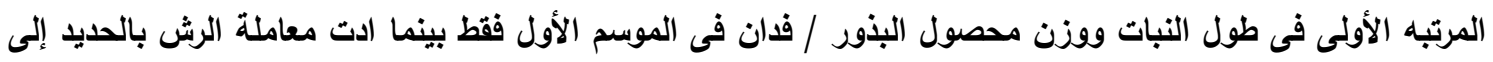

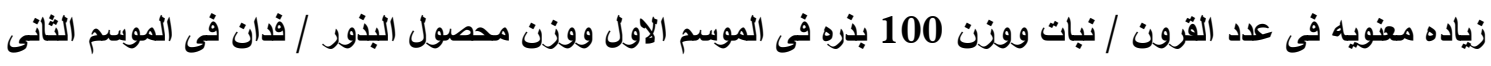

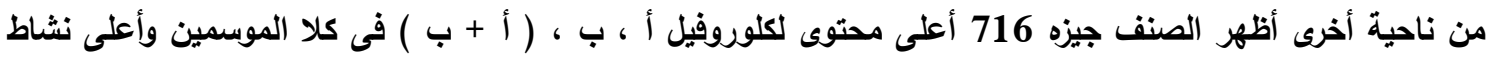

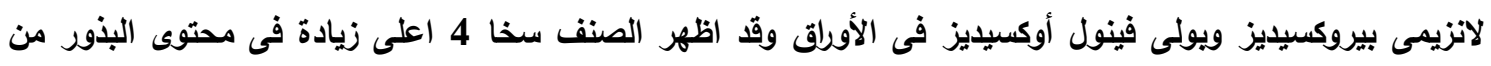

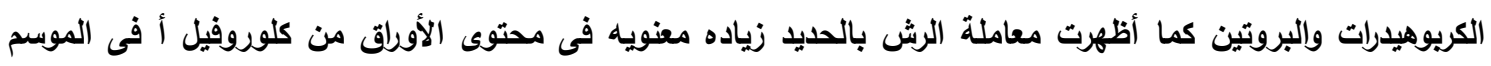

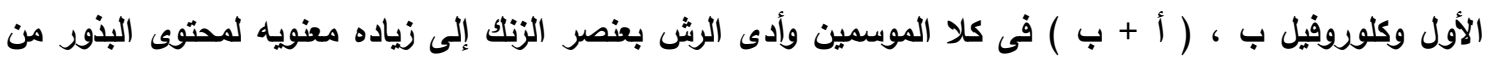

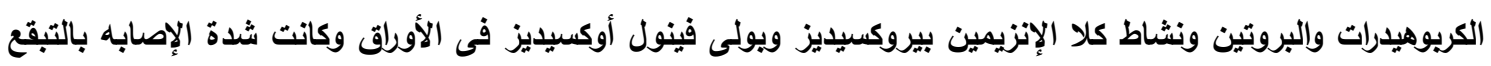

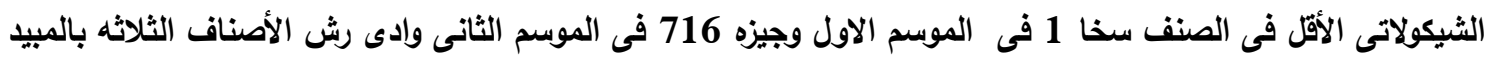

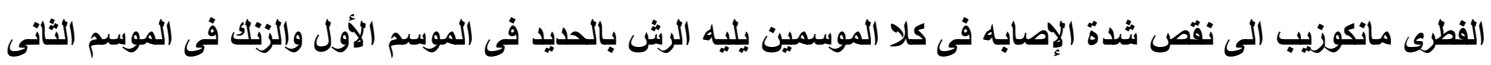

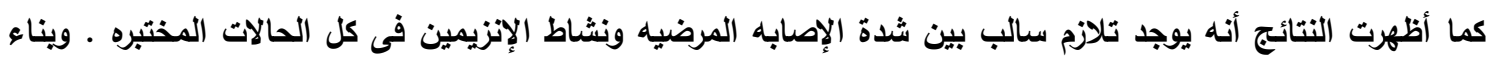

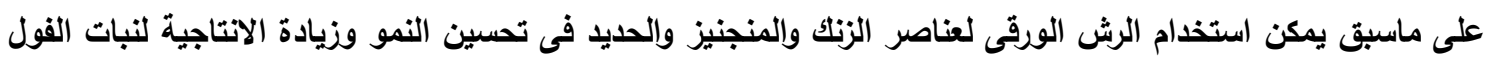
البلاى وكنلك التقليل من التاثير الضار لفطر البوترايتس علي النبات.

السادة المحكمين

كلية الزراعة - الثناطبى - جامعة الأسكندرية أ.د// سامى شعبان الطباخ

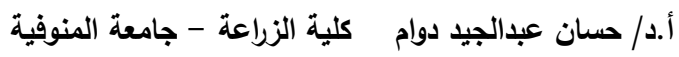


Effect of foliar spraying of some chelated microelements on growth, yield .......... 